\title{
Recasting the National Narrative Postcolonial Pastiche and the New Sierra Leone Peace
}

\section{and Cultural Monument}

\author{
Paul Basu
}

ALL PHOTOS BY THE AUTHOR, EXCEPT WHERE OTHERWISE NOTED

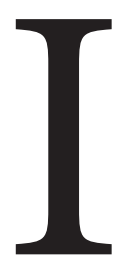

n February 2011, as Sierra Leone prepared to celebrate the fiftieth anniversary of its independence, a new national monument was opened to the public at the very center of Freetown. Actually, this was the second formal opening of the monument: the first had taken place twelve months earlier, on a newly instituted annual "Armed Forces Day," when President Ernest Bai Koroma officially unveiled it before members of the Republic of Sierra Leone Armed Forces (RSLAF). In the period between these two unveilings, the banner over its entrance gates, which originally bore the name "Monument in Remembrance of Our Fallen Heroes and Heroines," was replaced with another that reads "Sierra Leone Peace and Cultural Monument." In this way-enunciatively at least-a military war memorial was transformed into a civilian monument promoting peaceful coexistence through a shared national culture and history (Fig. 1).

A year in the making, and then another year "under wraps" while it was transferred to civilian management, the monument had attracted a great deal of attention from passers-by, who marvelled at the gigantic cement sculptures that took form (and then seemed to languish) behind guarded fences. Photographing the monument, even through the iron railings around its perimeter, was strictly prohibited. Alas, now that it has finally been opened to the public, the passers-by appear to have lost interest, no doubt put off by the advertised entrance fees: between Le500 and Le2,000 for children, Le5,00o for adults, and Le10,00o for non-nationals. Impressive though this colorful cement fantasia may be, with over $75 \%$ of Sierra Leone's population currently surviving on less than $\$ 2$ a day (currently about Le9,00o) (United Nations 2009), it is hardly surprising that few would consider spending what little cash they have on something so ... "symbolic"?

Already the paint is peeling from the cement statues and bas- relief sculptures that visually narrate this particular iteration of Sierra Leone's national history. And yet, despite its seemingly questionable value to many Freetownians, the monument represents a fascinating assemblage through which to reflect upon how public art-and public space-is being used (or at least sanctioned) by the State to promote political agendas and forge a shared national consciousness in this West African society still coming to terms with the profound divisiveness of its recent civil war.

\section{NATIONAL NARRATION AND POSTCOLONIAL PASTICHE}

The leitmotif of the Sierra Leone Peace and Cultural Monument is a message of "unity in diversity," a multiculturalist doctrine promoted widely in Sierra Leone, including in its soonto-be-adopted new cultural policy (Government of Sierra Leone 2011). "We all nar wan" ("we are all one") declares a slogan in one of the monument's bas-relief panels, while, in another, a personal message from the senior military officer who conceived of the monument appeals to his compatriots: "There is so much in us that unites us than divides us as Sierra Leoneans. We must recognize this fact and learn to live with one another." These explicit messages provide the starting point for a reading of this memorial text. One objective of this article is therefore to explore how this integrative narrative-what Homi Bhabha describes as the "progressive metaphor of social cohesion" (1990:294) - is articulated through the bringing together of the various components that make up the monument. In the incorporation of Sierra Leone's civil war into a shared, triumphalist national history, for example, we can detect that "active process of remembering to forget" that many such memorials depend upon as they recast incomprehensible loss and suffering into sacrifices made meaningful as the catalysts that bring about "a better tomorrow" (Rowlands 1998:55). 


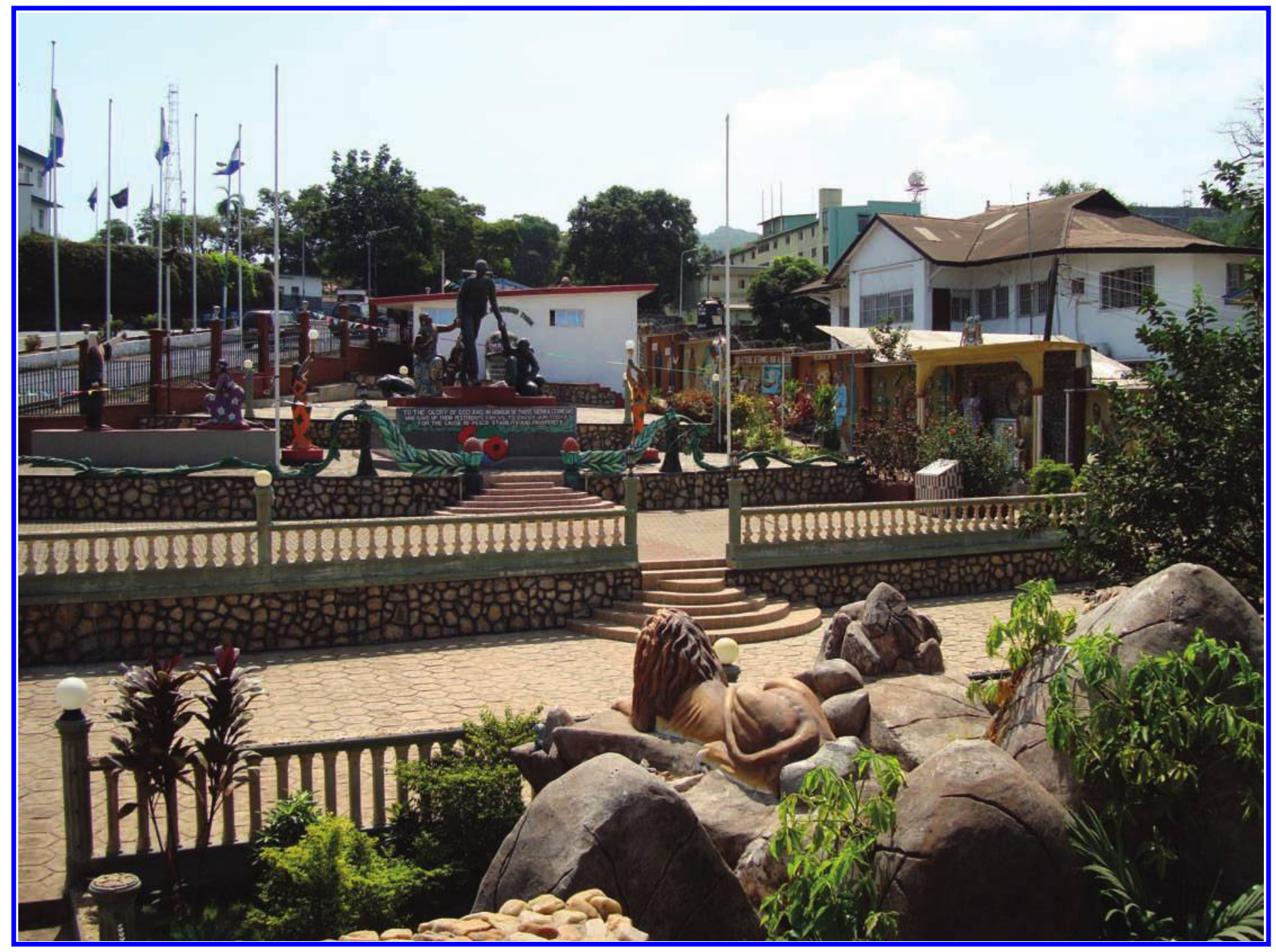

In contrast to the sombre understatement of many Western war memorials, however, there is an excess in the assemblage of forms, statements, and juxtapositions at the Peace and Cultural Monument that gives the site an accumulative power and vibrancy, but which also acts to undermine its integrative narrative. Here is the disjunct between the "certainties of nationalist pedagogy" and the "shreds and patches of cultural signification" that, for Bhabha (1990), places ambivalence and not unity at the heart of such sites of national narration. In this article, I should therefore like to look beyond the pedagogical narrative and to consider the monument as a site of ambivalence, a site expressive of its own contradictions. In order to do so, I am interested in exploring the concept of pastiche, and specifically what I refer to as "postcolonial pastiche." Whereas pastiche is burdened with negative connotations of shallow imitation, forgery, and travesty, here I follow the recent work of Ingeborg Hoesterey (2001) and Richard Dyer (2007) in seeking to rehabilitate this genre as a complex narrative form, similar to collage, but which has a distinct relationship with the past from which it quotes, and which crucially retains an aura of indeterminacy and ambiguity.

The play of conjuncture and disjuncture within the monument's multiple narrative temporalities is key here. Thus, as I shall go on to discuss and critique, statuary evoking the heroism of Sierra
1 General view of the Sierra Leone Peace and Cultural Monument, March 2011.

2 Sketch plan of the monument at the center of Freetown.

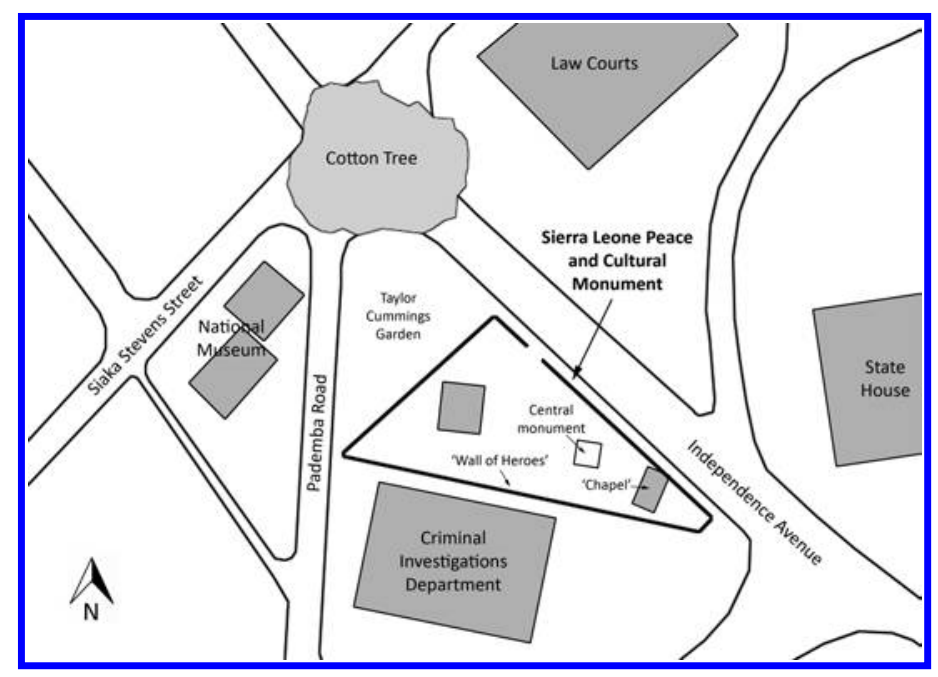




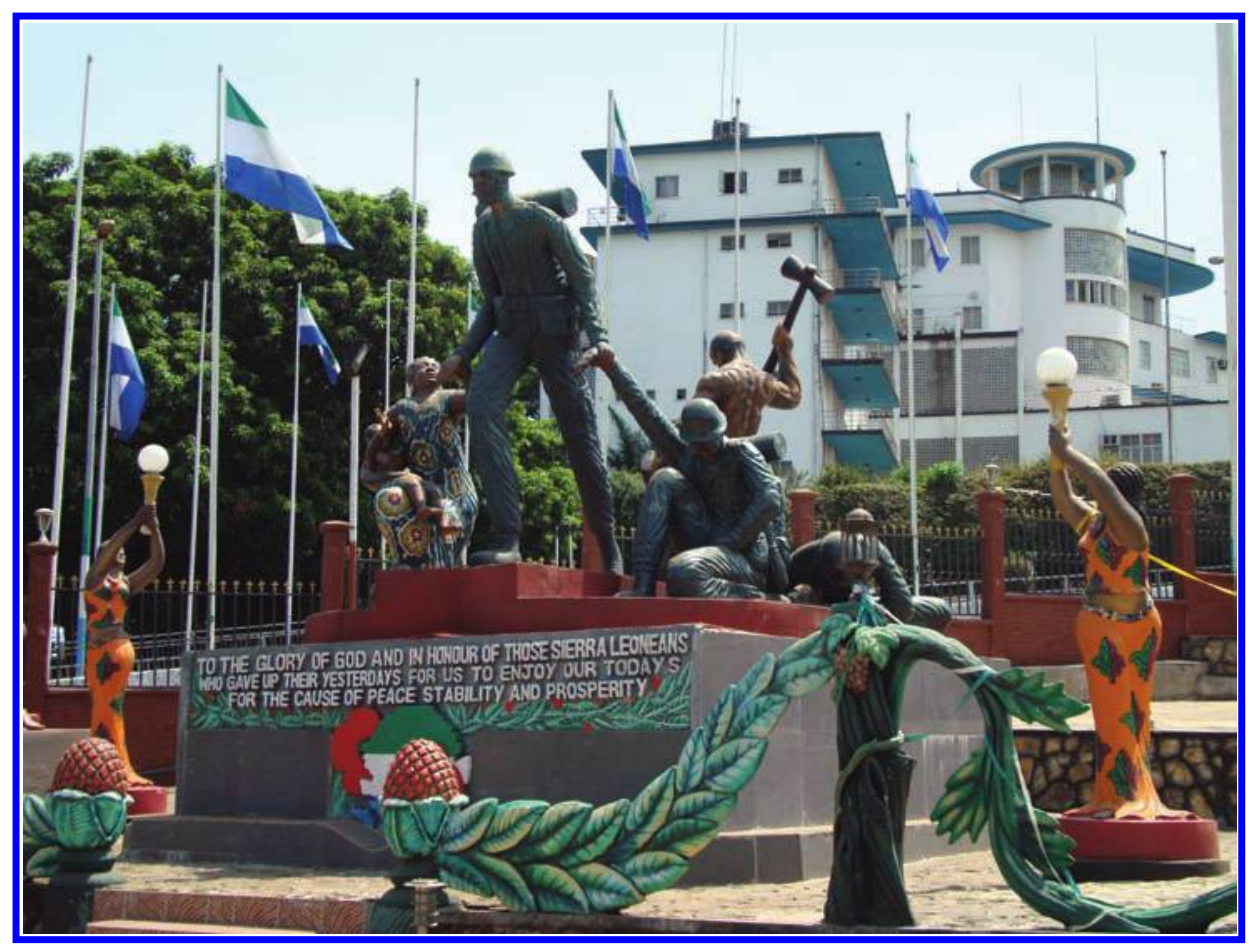

3 The central monument. In the background is State House, the Office of the President.

4 "Isaiah Man" flanked by the two fallen soldiers. In the background is the new CID building.

Leone's armed forces during the civil war is placed in relation to a sequence of bas-relief sculptures that articulate a heroic narrative of Sierra Leone's emergence as a modern, free, and independent postcolonial nation. In so doing, the civil war becomes continuous with a history of national self-determination, which distances itself from, and even denies, the agency of external forces-especially those associated with British colonialism. Within this narrative, the impact of colonialism is characterized as an aggressive intrusion that has, like the civil war, been overcome and placed in the past. At the same time as underplaying the complexity and continuing impact of colonialism, however, the monument ironically seems to reproduce colonial and neocolonial power relations in the present. This is manifest, I suggest, in the aesthetic of postcolonial pastiche, which, while constituting an authentically local form, knowingly or unknowingly draws its iconography and its repertoire of images and motifs from the colonial archive and other external sources.

Pastiche can be intentional or unintentional, and the significances that emerge in its "intertextual fabric" are highly perspectival (Hoesterey 2001:31). On the one hand we might perceive here a kind of "aesthetic dependency," that speaks to the broader structural dependencies of many postcolonial African nations as they continue to negotiate the economic, social and political legacies of colonialism. On the other hand, we might recognize a more politically driven mimetic appropriation of (neo)colonial form, which takes possession of, or is possessed by, the power of the transnational iconography it mimics (Taussig 1993). Then again, such a bountiful "gathering together" of images, forms, and statements-including richly ornamented cement representations of lions and elephants, rocks, waterfalls, pineapples, foliage, coats of arms and insignia, in addition to the elements I shall describe below-is also consistent with broader West African accumulative aesthetics and displays of wealth, power, increase, and abundance (Rubin 1975; Rowlands 2009, 2011). I suggest that the concept of postcolonial pastiche allows for the retention of this plurality of meaning when considering the plurality of form of this fascinating new monument.

\section{DEVELOPMENT OF THE MEMORIAL}

The creation of an official war memorial to commemorate the victims of Sierra Leone's civil war has been discussed since the end of the conflict in 2002. Following the recommendations of Sierra Leone's UN-funded Truth and Reconciliation Commission (TRC), which operated in Sierra Leone between 2002 and 2004, a National War Memorial Committee was established in the Ministry of Presidential Affairs and public competitions were held to elicit designs for memorials in Freetown and the provincial capitals of Bo, Kenema, and Makeni (Basu 2007:24246). Despite a continued emphasis on the value of memorials as mechanisms of transitional justice in the TRC's published report (Truth and Reconciliation Commission 2004:264), and the pro-

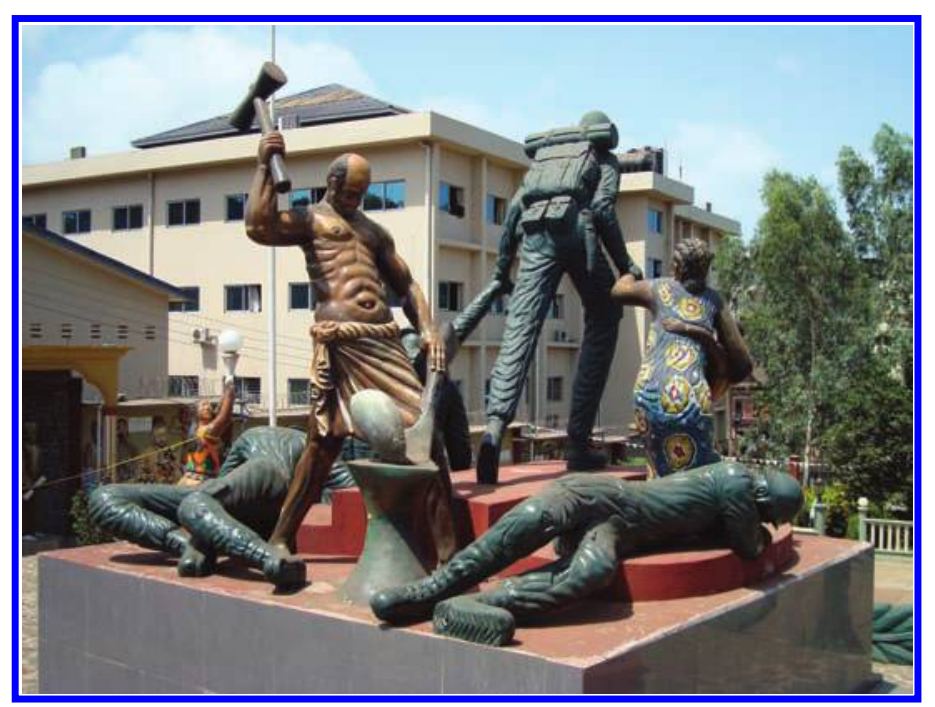


vision of a budget for the implementation of a "symbolic reparations" program, the only significant memorial to be erected by the Government of Sierra Leone in the immediate aftermath of the conflict was at Bomaru, a village in the country's Eastern Province where the first shots of the war were fired in 1991 (Mansaray 2006, Sajuma 2008). The election of President Koroma in 2007 marked a shift to a more presentational style of government in Sierra Leone, which was also more alert to the use of public spaces to communicate "public relations" messages and promote policy agendas. This regime was therefore more receptive to a proposal from the newly appointed Chief of Defence Staff, Major-General Alfred Nelson-Williams (now retired), to revive the idea of creating a new war memorial in Freetown.

What would eventually become the Sierra Leone Peace and Cultural Monument was first conceived by Nelson-Williams along with a corporal of the RSLAF named Inah Dixon, who is also a self-trained artist. Dixon explained to me that he had long harbored an ambition to create such a monument and, when Nelson-Williams was promoted to Chief of Defence Staff in 2008, he suggested to the Major-General that this would be an effective way of creating a legacy. "If you erect a monument," Dixon recalls saying, "that will make you a big man and, even after you leave post, people will remember you." Dixon subsequently accompanied Nelson-Williams on a bilateral friendship mission to neighboring Guinea, where they were inspired by the concrete statuary they encountered around Conakry. On returning to Sierra Leone, Nelson-Williams commissioned Dixon to create a statue of President Koroma, flanked by two bodyguards, at the new headquarters of the Ministry of Defence. This was the first large-scale cement sculpture that Dixon had undertaken, but it was evidently such a success that Nelson-Williams deter-

5 Perspex "tablets" recording the names of the SLA dead of the civil war.

6 "Tomb" of the unknown soldier.

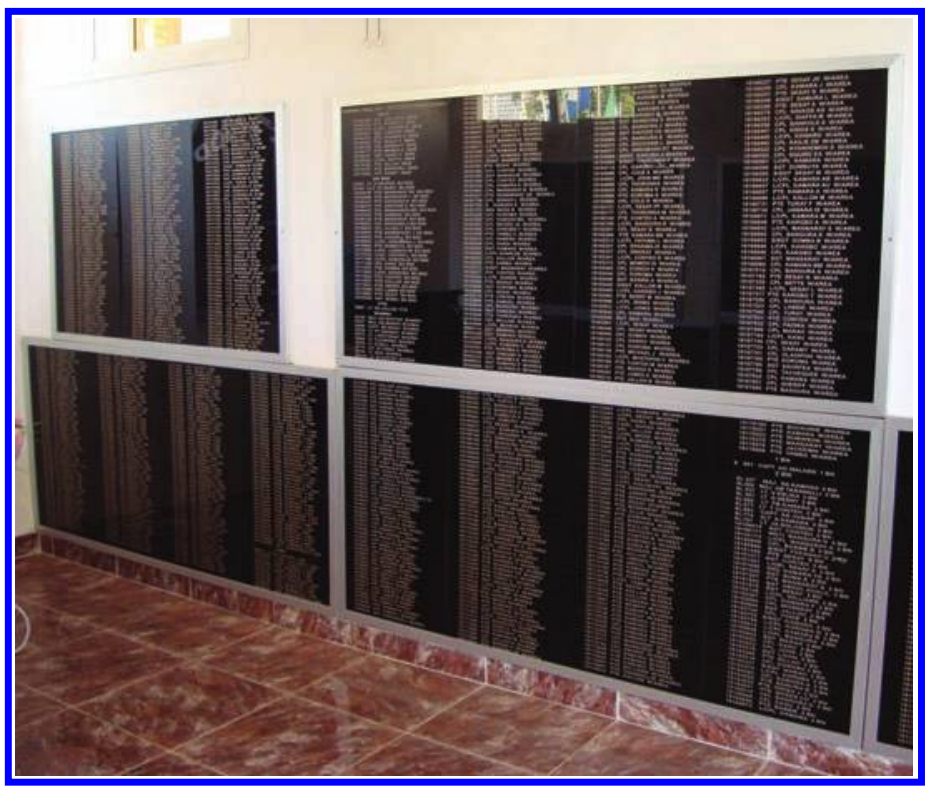

mined that he would find a suitable plot on which to erect a more ambitious memorial in remembrance of the RSLAF soldiers who had been killed fighting in Sierra Leone's civil war.

A vacant plot of land was duly given over by the Government to the memorial project at the heart of Freetown, and work commenced in March 2009. The location of the site is highly significant, being juxtaposed with State House (the Office of the President), the Law Courts, the National Museum of Sierra Leone and, perhaps most importantly, Freetown's famous Cotton Tree (Fig. 2). At the first official unveiling of the monument, on February 18, 2010, before the gathered ranks of the RSLAF as well as senior figures from government, the military, and various diplomatic missions, Koroma noted the location of the monument at "the very center of our capital," where it "shall always remind us of our patriotic compatriots who sacrificed their lives to secure our motherland" (Koroma 2010).

The monument, which might be better described as a small sculpture park, was largely financed by corporate sponsorship, most significantly by a prominent Lebanese businessman, Ezzat Basma, and his family. It was Basma who first showed me around the newly unveiled park in March 2010. With evident pride he described the significance of the various components of the memorial: its sculptural figures and friezes, its chapel of remembrance, and the building that was intended to house a restaurant-bar, the profits of which would provide funds for the monument's upkeep. I have subsequently revisited the monument with various other individuals involved in the project. Alongside Dixon, the artistic work was led by two other wellknown Sierra Leonean street artists, Samuel Marco and Alusine Bangura, under the overall direction of Nelson-Williams.

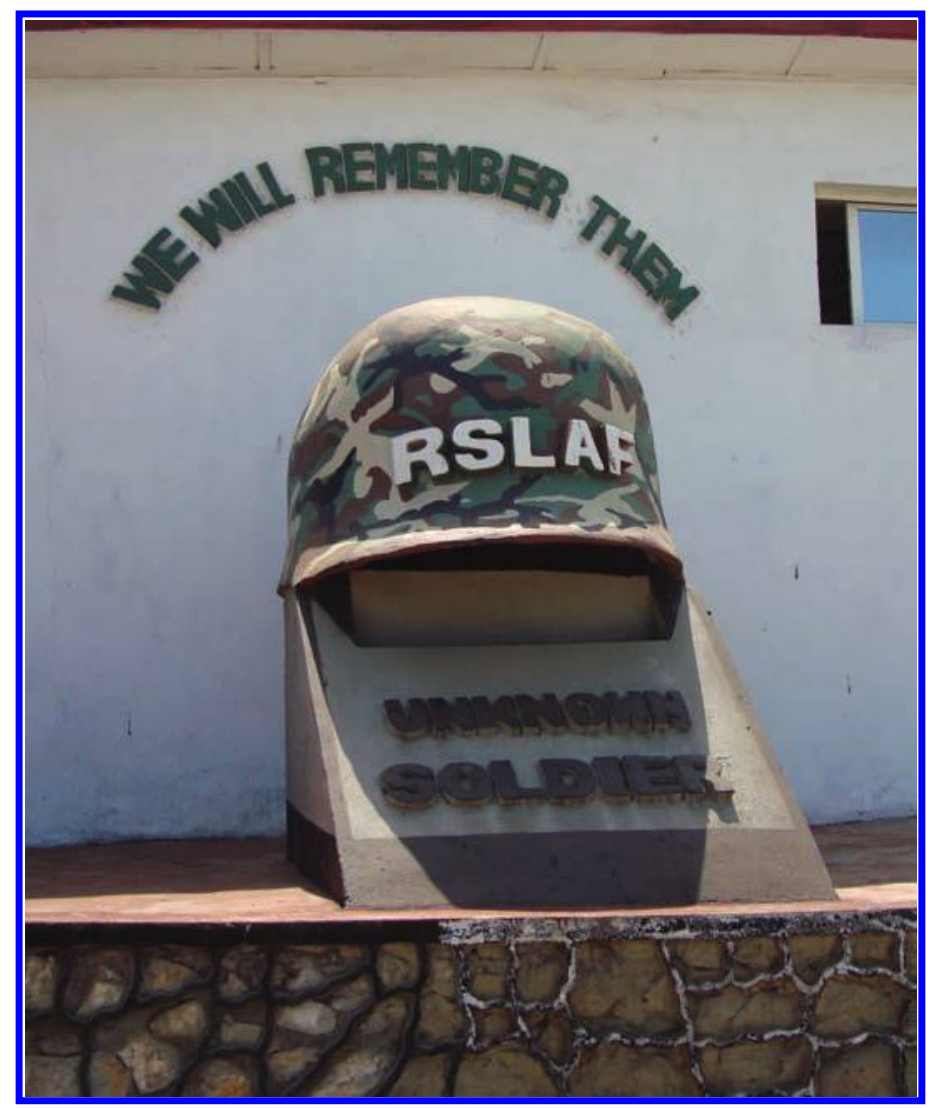




\section{FROM WAR MEMORIAL TO PEACE MONUMENT}

The fact that the monument was originally conceived as a military memorial, and not an instrument of symbolic reparation as anticipated by the TRC, is apparent as one wanders around the site. The gargantuan assemblage at the center of the enclosure features a striding, heroic male soldier pulling upwards and onwards a pleading woman with a child in her arms in one hand and a wounded or weakened male comrade in the other (Fig. 3). The gaze of this moustachioed soldier-savior is fixed firmly before him and, whether by design or coincidence, is directed towards Freetown's Cotton Tree, a powerful unifying symbol of the Sierra Leonean nation (Basu 2007). Recumbent on the plinth behind these figures are the dead or dying bodies of two other soldiers who have evidently fallen in combat. A temporal order is suggested in the assembled tableau: a need to put the carnage of the recent past behind one and to resolutely face the future. And, of course, it is the stoical face of Sierra Leone's Armed Forces which selflessly leads the nation towards that future.

Needless to say, it is nowhere acknowledged within the memorial that the Sierra Leone Army (SLA) is known to have perpetrated a significant percentage of the human rights violations committed during the civil war. There is no attempt to confront the undisputed findings of the TRC that "the SLA failed the people of Sierra Leone," and indeed "acted against ... the very people it was meant to defend," perpetrating "extensive human rights violations against the civilian population" (Truth and Reconciliation Commission 2004:50). The terrifying indistinction between government and rebel forces that emerged during the war was reflected in the coining of the portmanteau term "sobels" "soldiers by day, rebels by night" (Zack-Williams 1997) - and necessitated the complete reformation of Sierra Leone's armed forces in the immediate post-conflict period. Part of this process involved the reconstitution of the SLA as the RSLAF in 2002, and it could be argued that the creation of the new war memorial/peace monument is another step towards rehabilitating public perceptions of Sierra Leone's military forces. In this context we might perhaps interpret those recumbent soldiers as representing both those fallen heroically in defence of the nation and those fallen ignominiously from grace as soldier-rebels. Either way, they are presented in the monument's spatiotemporal configuration as belonging to a traumatic past that must be overcome and left behind if Sierra Leoneans are to once more "learn to live with one another." Indeed, the ambiguity over who were the heroes and who the villains in Sierra Leone's civil war is reflected in the imprecision of the text emblazoned along the front of the monument's plinth. The dedication simply reads, "To the glory of God and in honour of those Sierra Leoneans who gave up their yesterdays for us to enjoy our todays for the cause of peace, stability and prosperity."

To the rear of the plinth is another figure, a bare-chested man-a blacksmith-wielding a hammer with which he is beating a gun into a ploughshare on an anvil (Fig. 4). Dixon explained to me that they called this figure "Isaiah Man," referencing Isaiah 2:4, "They will beat their swords into ploughshares and their spears into pruning hooks. Nation will not take up sword against nation, nor will they train for war anymore." Aside from the semi-automatic rifle he is reshaping, the figure certainly appears to have

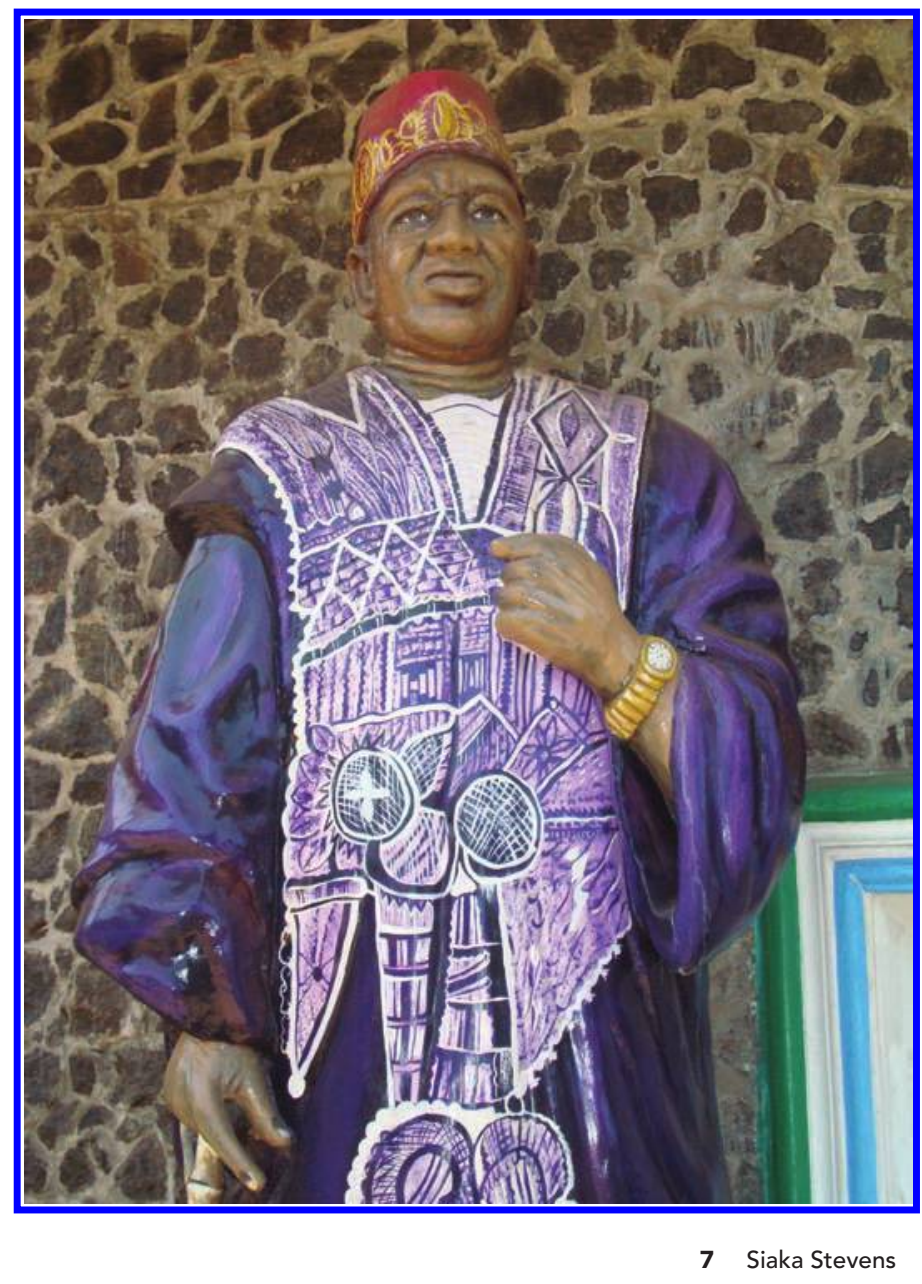

stepped out of the Old Testament, yet his un-uniformed state also suggests that he represents a premodern, precolonial indigenous African presence. Dixon mentioned that the ploughshare signifies agricultural development in Sierra Leone, a prominent objective of Koroma's "Agenda for Change" manifesto. In Isaiah Man, then, we find a traditional figure from the past holding a key to Sierra Leone's economic independence in the future.

There is a modernist solidity to the figures in the memorial's central monument that is redolent of post-World War II Soviet memorials. Yet, on the front of the monument's plinth, superimposed on a map of Sierra Leone painted in the national colors, are red poppies borrowed from Flanders Fields and from British and North American World War I commemorative iconography. Here we see a more explicit articulation of the aesthetic of pastiche, which is promiscuous in its imitation and combination of existing commemorative motifs. On one level the incorporation of such motifs might be regarded as a kind of shallow simulacra, but at the same time this also evinces a complex temporality at work in the monument as it "remembers" other monuments of remembering. The "cultural codifications" rearticulated within the work of pastiche do not emerge from nowhere, but are available within the social, cultural, and historical contexts in which the work is produced and, in this way, they represent a kind of cultural archive or memory, an intended or unintended inscription of the past in the present (Hoesterey 2001). Hence, the 


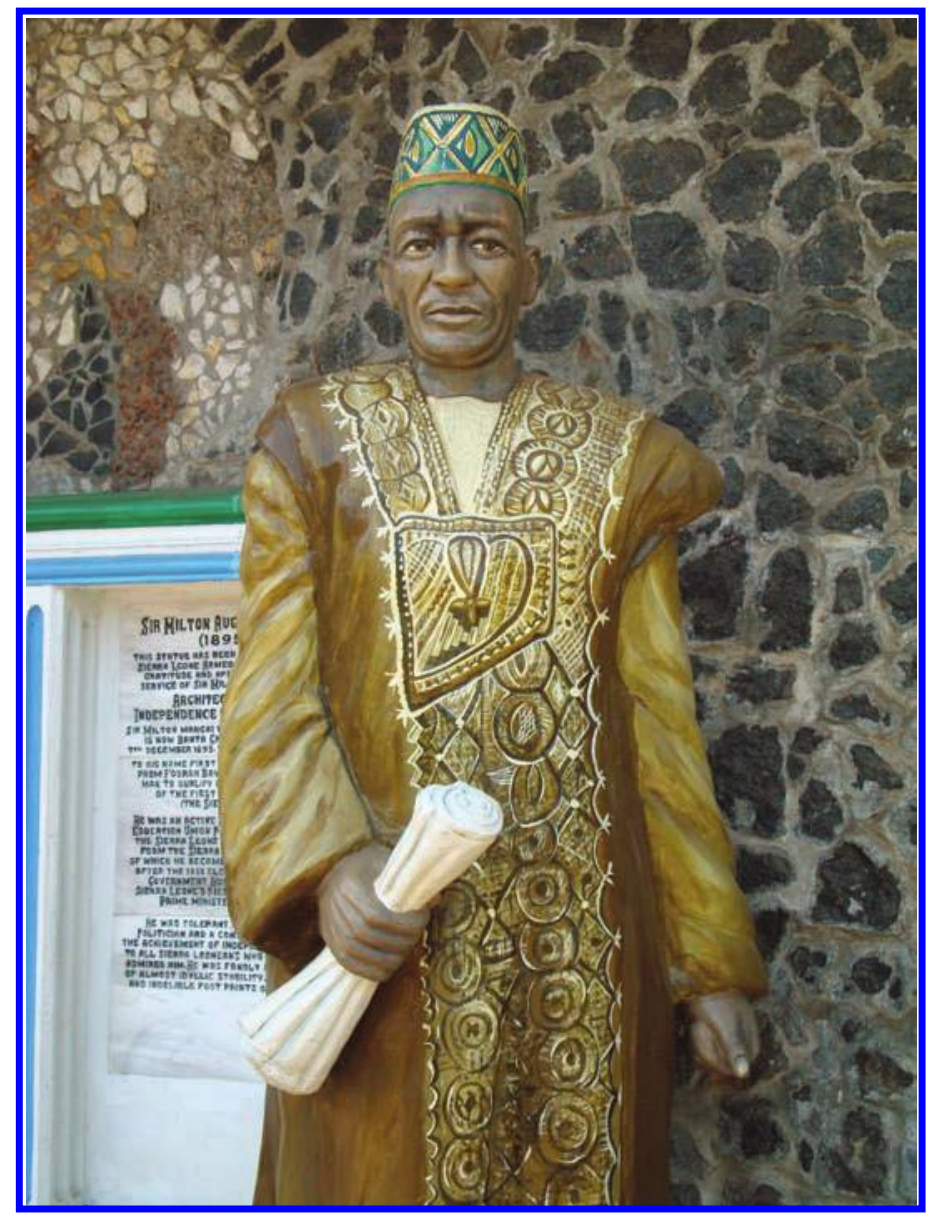

8 Sir Milton Margai

incorporation of the seemingly incongruous poppy motif into the new monument brings back to mind Sierra Leone's colonial history, including colonial forms of commemoration and a remembrance of the many hundreds of Sierra Leoneans who were killed fighting the wars of their erstwhile "colonial masters." Indeed, not far from the new monument, in front of the old Secretariat Building (the one-time heart of colonial governance in Sierra Leone), stands the colonial-era war memorial-known locally as "the cenotaph"-before which garlands of paper poppies are still annually laid. One wonders whether the significance of this somber stone and cast bronze memorial will soon be eclipsed by the color, scale, and theatricality of the new, immeasurably more authentically Sierra Leonean, ritual space of the nation.

\section{“WE WILL REMEMBER THEM"}

The imitative and combinatory qualities of pastiche are perhaps most forcefully expressed in the small, chapel-like building that stands at the southeastern corner of the memorial's enclosure. The construction of this chapel of remembrance was personally supervised by Ezzat Basma, the memorial's main sponsor. Either side of the doorway into this small, whitepainted building are two imitation marble angels. With their downcast eyes and hands clasped in prayer, they contrast sharply with the colorful, larger-than-life cement sculptures found elsewhere in the memorial, and would seem more typical of Victo- rian cemeteryscapes in Britain. Entering the building's interior, one faces an aluminium-framed black Perspex panel, on which is displayed the RSLAF insignia and a repetition of the original name of the memorial: "To the Glory of God: Monument in Remembrance of our Fallen Heroes and Heroines." In front of this stands a black lectern, flanked by imported stands supporting arrangements of artificial flowers. The side walls of the chapel's interior are covered by further black plastic panels, again framed in aluminium, onto which are printed in gold-colored letters the names of the soldiers killed during Sierra Leone's civil war (Fig. 5). Above the exit door, in bold, black letters, the unreferenced text is written, "Never was so much owed by so many to so few." Finally, alongside the exterior of the chapel, facing out onto the rest of the memorial, a gigantic concrete helmet, painted in camouflage, with the letters "RSLAF" emblazoned on the front, rests on a plinth representing an empty grave on which is written "Unknown Soldier." Above the helmet, mounted on the exterior of the chapel wall is the text, "We Will Remember Them" (Fig. 6).

It will be clear from this brief description that the memorial chapel epitomizes postmodern pastiche and its broader semantic environment, including cultural discourses of appropriation, bricolage, collage, fake, farrago, imitation, plagiarism, refiguration, simulacrum, and travesty (Hoesterey 2001). In this mélange we find unacknowledged quotation from Laurence Binyon's "For the Fallen" (1914), from Churchill's famous tribute to the RAF pilots who fought in the Battle of Britain (Churchill 1940), from the iconography of the tombs of unknown soldiers, first commemorated in Britain and France on Armistice Day 1920, and from the endless lists of names inscribed on slate or granite or cast in bronze on war memorials throughout Europe and North America. Like the poppy, all of these motifs have become part of a transnational iconography of war commemoration, and their repetition in the Sierra Leone Peace and Cultural Monument seems at first to speak of an aesthetic dependency whereby the architects of the monument have been unable to develop a more locally relevant response to the losses incurred in the conflict. Severed from their original cultural and historical referents, to Western eyes the affective properties of these motifs are diminished and, like the helmet of the unknown RSLAF solider (itself an anachronism, of course, since the RSLAF was not formed until after the end of the conflict), seem to become empty signifiers.

In many ways, however, this interpretation can be completely inverted, and the pastiche of the chapel can be used to demonstrate how, in West Africa, such ritual spaces can be made powerful and striking - and, indeed, laden with significationthrough the accumulation of "ready-made" symbols, statements, and forms. This sedimentation of ritual statements extends to the performative sphere too, for example in the repetition of visitors' expressions of "being moved to tears" that I have witnessed when they are confronted with the lists of names recorded there on the black plastic panels (statements unaccompanied by a corresponding outward display of emotion).

Shallowness and depth, superficiality and profundity coincide in such works of postcolonial pastiche, not least in the temporal admixture brought about through the juxtaposition of their mimicked forms. As Taussig argues, the mimetic faculty is not 

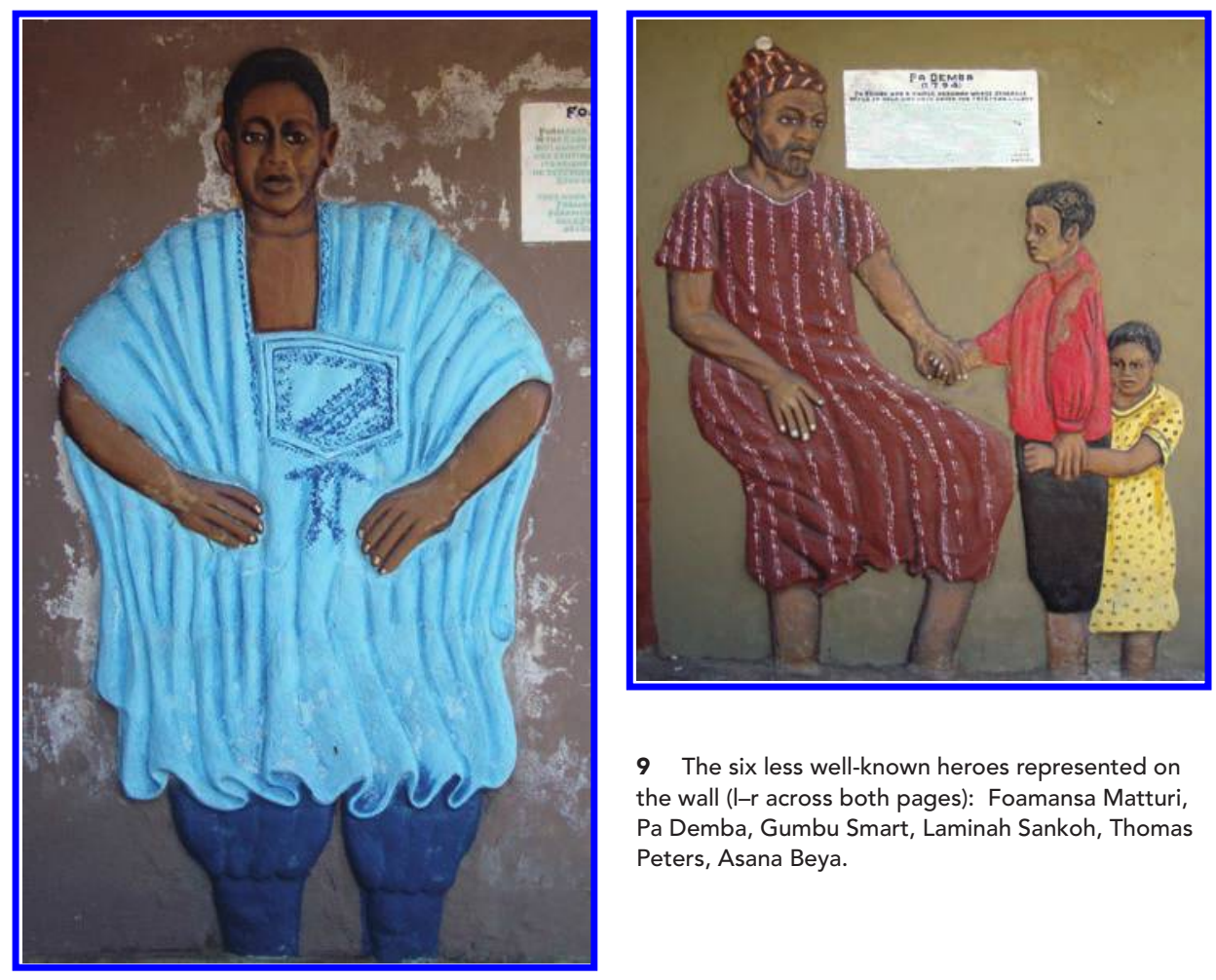

9 The six less well-known heroes represented on the wall (I-r across both pages): Foamansa Matturi, Pa Demba, Gumbu Smart, Laminah Sankoh, Thomas Peters, Asana Beya.

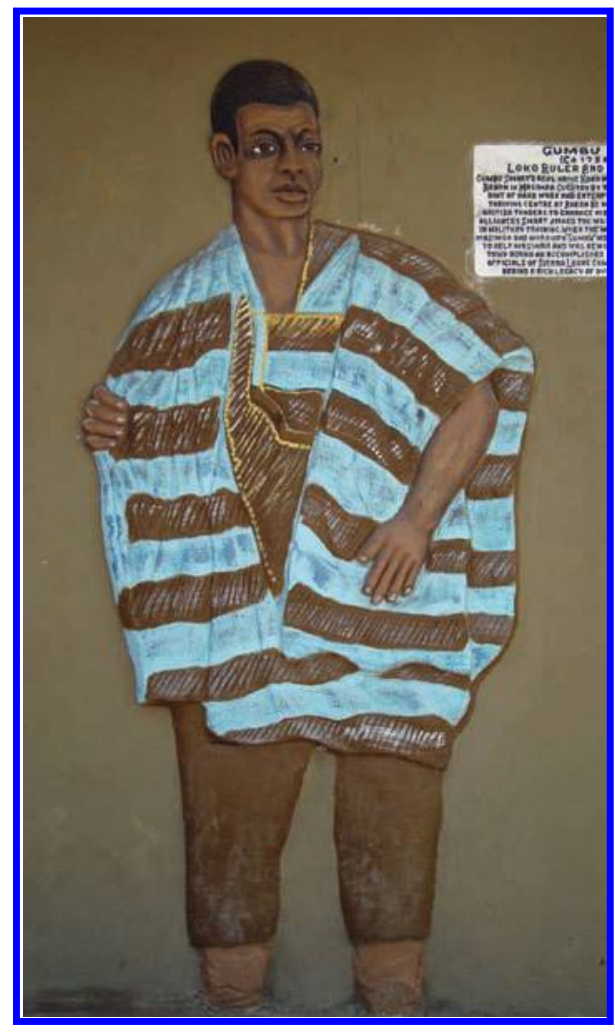

without its own histories, and "the history of mimesis flows into the mimesis of history" (1993:xviii). “To witness mimesis," he goes on, "to marvel at its wonder or fume at its duplicity, is to sentiently invoke just that history and register its profound influence on everyday practices of representation" (ibid.). At Sierra Leone's Peace and Cultural Monument, too, meaning is constructed by knowingly or unknowingly reappropriating, reassembling and recontextualizing motifs from the colonial past (as well as the transnational present). The mimetic act of pastiche is therefore also an act of remembering, which necessarily perpetuates a dialectical relationship between the postcolonial nation and its colonial history (Hoesterey 2001:25).

\section{THE "WALL OF HEROES":}

\section{RECASTING THE NATIONAL HAGIOGRAPHY}

Another dimension of this dialectical relationship between present and past can be explored at the Sierra Leone Peace and Cultural Monument by examining the colorful series of basrelief sculptures created along the long, southern boundary wall of the memorial complex. These painted cement tableaux depict various historical personalities who have become canonized as "Sierra Leonean heroes," notably since the publication of a book of that name in 1988 (Kabba 1988). As I have discussed elsewhere (Basu 2007), this sourcebook of patriotic imagery was itself the product of specifically North American cultural nationalist sensibilities imported into the Sierra Leonean context. In an account of the book's origins and its subsequent influence on patriotic street art in Freetown, Joe Opala, a Peace Corps volunteer and expatriate history lecturer from Oklahoma who lived in Sierra Leone between 1974-1977 and 1985-1997, explains that the Sierra Leonean Heroes book came about largely through his own efforts:
Noting the absence of patriotic imagery in Sierra Leone, I wrote a series of articles on "neglected heroes" for the [Sierra Leonean] Daily Mail newspaper in 1986, and also urged the government to produce a school book based on historical figures. In 1987 the former president appointed a committee to compile the book and I had the happy task, among others, of assembling photographs of the heroes and working with artists to produce drawings of historical figures for whom we had no pictures. I was keenly aware that we were creating patriotic icons and took pains to place the heroes in memorable poses and to ensure that their costumes were historically accurate (Opala 1994:201).

Opala goes on to discuss how he used the book as a reference text in a course entitled "Art, Anthropology, and National Consciousness" that he taught to an increasingly politicized student community at Freetown's Fourah Bay College. It was, however, in the aftermath of a military coup led by a number of disaffected young army officers in 1992 that its patriotic imagery came to be reproduced more widely. "With extraordinary suddenness," Opala relates, "images from the Heroes book appeared on walls throughout the city" (1994:201), and youth organizations were soon competing for artistic laurels by fashioning "symbols of patriotic pride based on history, culture, and political ideology" in a manner previously unseen in Sierra Leone (1994:198).

The degree to which the street artists who reproduced these "symbols of national consciousness" represented a truly "grass roots" movement, as Opala argues (ibid.), is debatable given his own participation in sourcing the original images (many of which are drawn from the colonial archive), shaping the representation of others in suitably "memorable" poses, and promoting cultural nationalism through newspaper articles and lectures. We might better understand theirs as a hybrid, "glocal" movement (Robertson 1995): on the one hand highly localized, on the other entangled in international power relations and global flows of images, aesthetics, and nationalistic ideologies. 

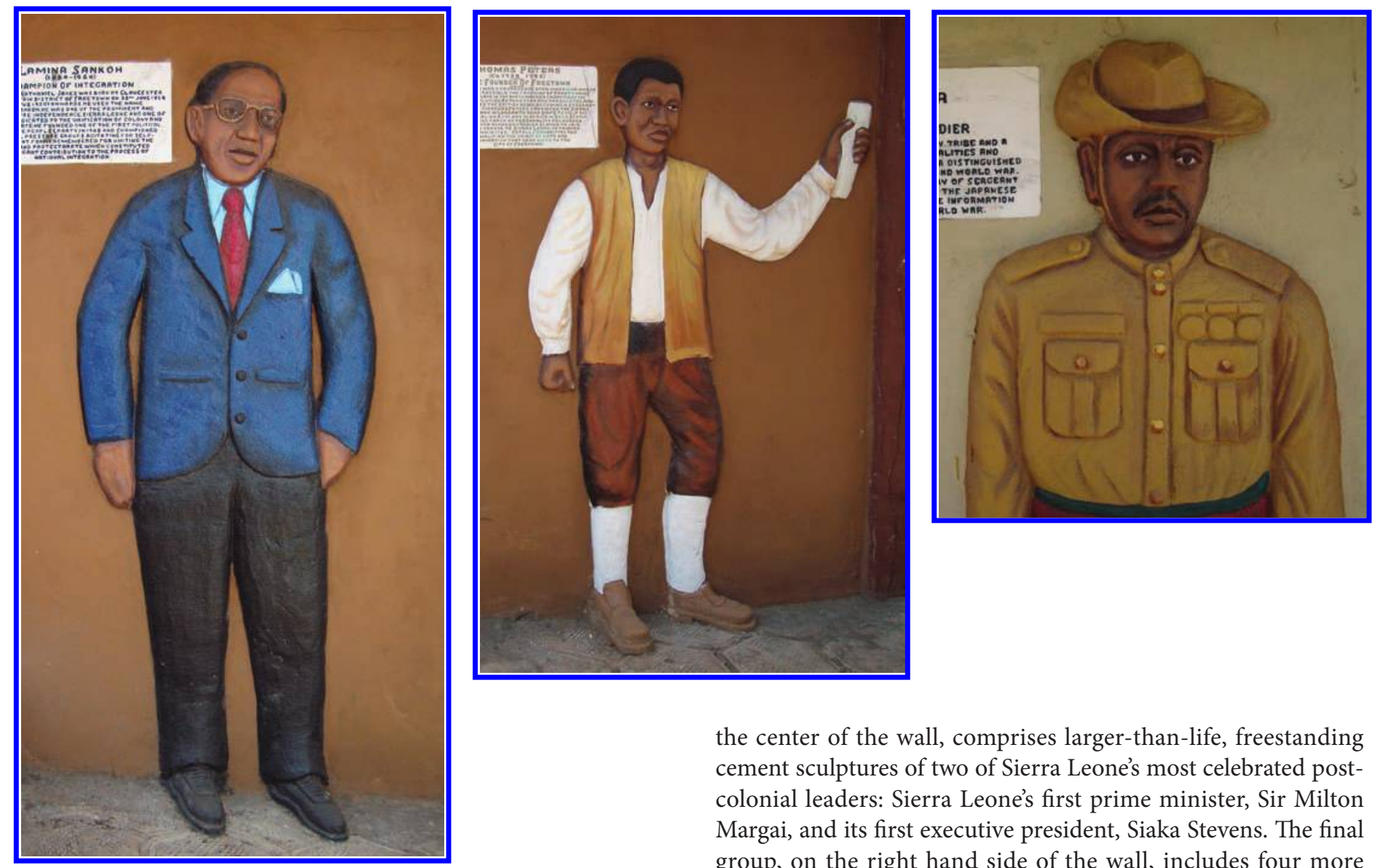

the center of the wall, comprises larger-than-life, freestanding cement sculptures of two of Sierra Leone's most celebrated postcolonial leaders: Sierra Leone's first prime minister, Sir Milton Margai, and its first executive president, Siaka Stevens. The final group, on the right hand side of the wall, includes four more elaborate bas relief tableaux, which incorporate but also depart more creatively from the images in the book.

The four tableaux in this final group, featuring John Akar, Madam Yoko, Sengbe Pieh, and Bai Bureh, are particularly interesting and deserve more detailed discussion. Before turning to these, however, I should like to reflect briefly on the other figures represented along the monument's "wall of heroes." The figures of the postcolonial heads of state, Siaka Stevens and Sir Milton Margai, are perhaps least surprising (Figs. 7-8). Whilst their respective leadership styles could not have been more different, as representatives of Sierra Leone's two major political parties (the All People's Congress and the Sierra Leone People's Party), the co-presence of their statues, side-by-side at the center of this wall, provides a political balance in keeping with the monument's reconciliatory "unity in diversity" message.

The selection of the six lesser-known heroes along the left hand side of the wall appears more arbitrary (Fig. 9). The choice seems partly to have been informed by a need to include representation of a wide range of Sierra Leone's major ethno-linguistic groups. Thus, among the twelve figures, are members of Sierra Leone's Temne, Mende, Limba, Krio, Kono, Kuranko, Sherbro, Loko, and Lebanese populations. Despite the absence of Mandingo, Fula, Susu, Kissi, Yalunka, and Vai representation, the choice of heroes is thus broadly inclusive. Examining the texts inscribed on the adjacent plaques one can also discern how these lesser-known heroes are portrayed as embodying personal characteristics worthy of emulation. In a country in which positive and negative "tribal" stereotypes still abound, the message appears to be that, regardless of ethnic affiliation, these heroic ancestor figures are 

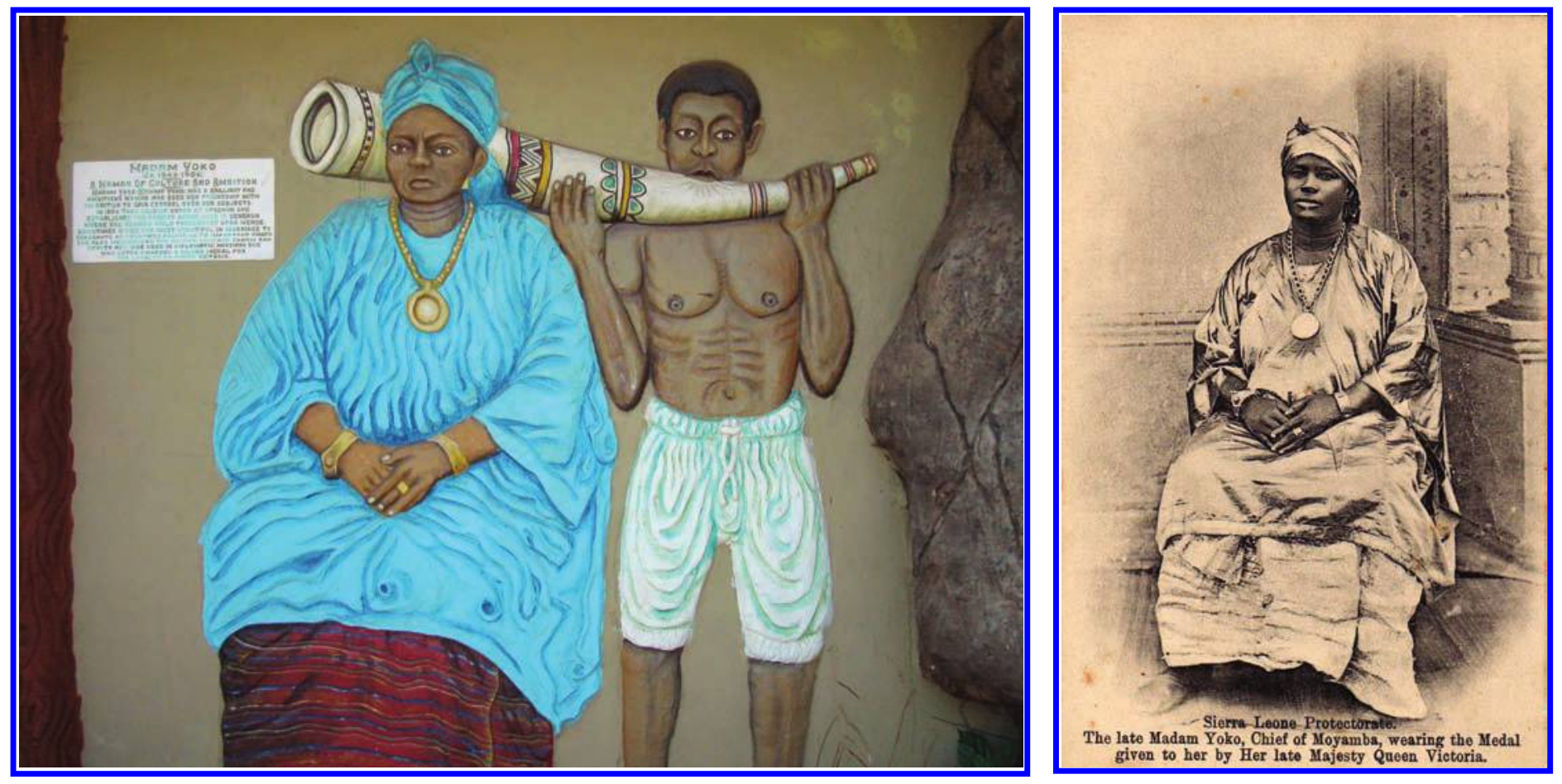

(clockwise from top left)

10 Madam Yoko tableau.

11 W.J. Johnson's studio photograph of Madam Yoko, published as a postcard in c.1906. PHOTO: COURTESY OF GARY SCHULZE

12 Detail of T.J. Alldridge's photograph showing Momoh Kaikai and hornblower. Late 19th century. PHOTO: COURTESY OF ROYAL PAVILION AND MUSEUMS, BRIGHTON AND HOVE

all exemplary Sierra Leoneans and, as such, models for current generations to live by.

The particular qualities that these heroes represent, however, reflect the wider ambiguity of the sculpture park, caught in its schizophrenic identity as both war memorial and peace monument. Thus, qualities of gallantry, bravery, and fighting ability sit alongside less militaristic characteristics of diplomacy, entrepreneurship, hard work, and the ability to initiate "development projects." Figures such as Pa Demba, Thomas Peters, and Sengbe Pieh demonstrate how ordinary people can be transformed into heroes through their generosity, commitment, spirit of hope, and their courage to stand up for what is right. Pa Demba, in particular, stands for the triumph of humanity over tribal or political divisions, and the possibility of an indigenous people opening its arms in compassion to an incoming settler society. Yet, of course, like all hagiographies, these biographical texts are also mythical accounts of the "lives of heroes": next to nothing is actually known about Pa Demba, and the degree to which Thomas Peters was the "true founder" of Freetown is debatable, as is the seeming singlehandedness with which Asana Beya ended World War II. It is interesting, for example, to compare these accounts with the more objective, if still celebratory, biographical notes in Magbaily Fyle's Historical Dictionary of Sierra Leone (2006).

Even more ambiguous is the fact that a number of the chiefly heroes represented on the wall were not figures of national unity at all, but established their reputations as aggressors, expand-

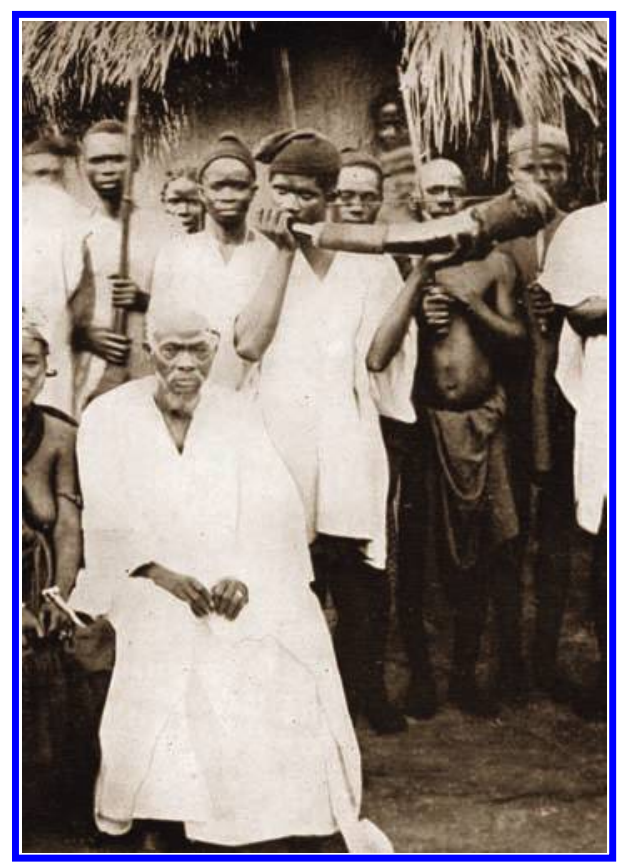

ing the interests of their own polities often against groups with which they now share a national identity. Similarly, whilst the monument celebrates Sierra Leone's place in the history of emancipation and the abolition of slavery (most explicitly in the figures of Thomas Peters, Sengbe Pieh, and an anonymous freed-slave figure I shall discuss later), among the heroes represented is Gumbu Smart, who was a prominent slave trader and middleman (Fyle 2006:190). These contradictions signal broader inconsistencies between the narratives produced through postconflict transitional justice mechanisms, such as the TRC, which often posit imagined prewar histories of peaceful coexistence, with the realities of the region's past, which, it could be argued, is largely a history of conflict and shifting alliances (Basu 2008). 

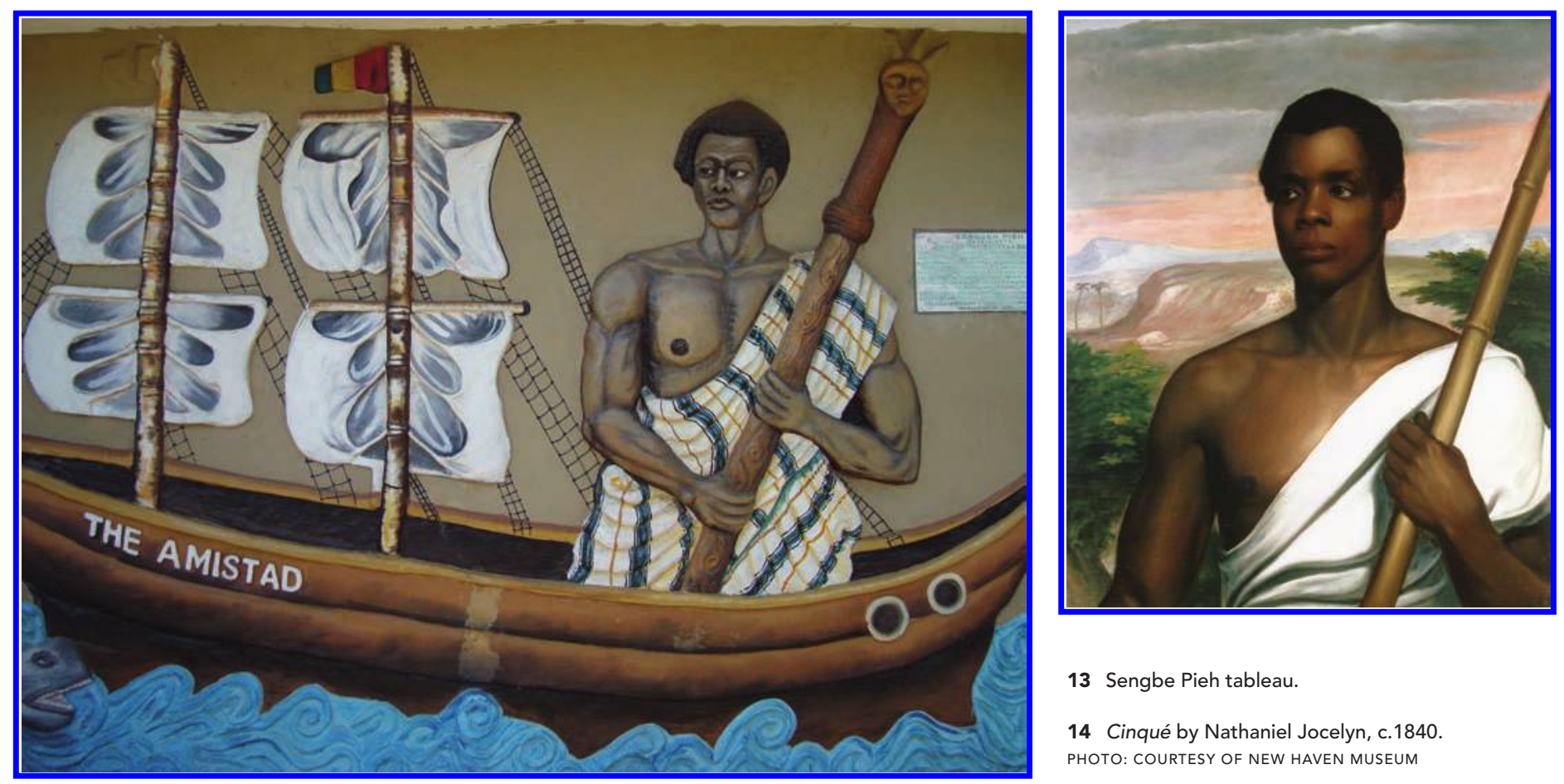

13 Sengbe Pieh tableau.

14 Cinqué by Nathaniel Jocelyn, c. 1840 PHOTO: COURTESY OF NEW HAVEN MUSEUM

The figures of Madam Yoko and, particularly, Sengbe Pieh and Bai Bureh are well-known to many-perhaps most-Sierra Leoneans, and the same iconic images of them are repeated in murals, cement statues, and even coins and banknotes. These were among the most popular historical personalities to be painted by street artists in the post-1992 coup era and a few examples of Sengbe Pieh cement statues from this period can still be seen in Freetown: for example, at Congo Cross and, until recently, in the garden of the National Museum. The prominence of these national heroes in Sierra Leonean popular culture is reflected in the more elaborate pictorial representation they are given in the Peace and Cultural Monument. This includes a greater degree of quotation and recombination compared with the other portraits on the wall of heroes. And here it is worth noting again that Dixon's main collaborator in these bas-relief sculptures was Alusine Bangura, who has been repeatedly fabricating representations of these same characters, drawing upon the same source materials, refining the art of postcolonial pastiche, for over twenty years.

Of these three tableaux, that representing Madam Yoko (Fig. 10 ) is the most straightforward, yet even here we find an ambiguous tension between the elements combined in the pastiche. The inclusion of Madam Yoko is significant in as much as she is the only female Sierra Leonean hero included in the monument (recalling that the original name of the site was the "Monument in Remembrance of Our Fallen Heroes and Heroines"). Indeed, as a powerful female chief adept at building strategic alliances and exploiting British colonial interventions to her own advantage, she has become something of a feminist icon among both women's empowerment groups within Sierra Leone and Western feminist scholars (e.g., Hoffer 1974). Interestingly, her association with the female Sande society - an initiation society that is criticized by human rights campaigners in Sierra Leone and internationally for its continued practice of female circumcision-is not expunged from the narrative on the tableau's plaque, nor is the fact that she used its members strategically to extend her political influence-"giving the most beautiful in marriage to sergeants of Frontiers Police or to important chiefs," as the plaque inscription explains. Madam Yoko's inclusion in the monument as a female role model therefore sits uneasily with the promotion of gender equality and women's empowerment articulated in the Government of Sierra Leone’s "Agenda for Change" policies, and championed by numerous civil society pressure groups.

The Madam Yoko tableau combines two separate components from the Sierra Leonean Heroes book, which are themselves unacknowledged reproductions of older sources. The foreground image of Yoko herself has its origins in a studio portrait of the chief taken by W.S. Johnston, a Creole photographer, possibly from Liberia, who established a studio in Freetown in the late nineteenth century (Viditz-Ward 1987:513-14). In the photograph, Yoko is sitting with her hands resting together on her lap. She looks directly to camera. She wears a large ring on the middle finger of her left hand, large bracelets on her wrists, and an impressive medallion on her breast, which hangs from a heavy chain around her neck. All of these features, as well as her headscarf and garments, are scrupulously reproduced in the bas-relief sculpture. It is likely that the photograph was taken between 1898 and 1901. It was subsequently published as a postcard after Yoko's death in 1906, with the following caption: "Sierra Leone Protectorate. The late Madam Yoko, Chief of Moyamba, wearing the Medal given to her by Her late Majesty Queen Victoria" (Fig. 11). What is not reproduced is the painted backdrop of the photograph, which is itself, of course, a pastiche, evoking high status European décor. In the tableau, Yoko is instead placed against a neutral, "up-country" background, and positioned in front of a traditional hornblower holding a decorated ivory horn to his mouth. This hornblower figure is borrowed from the line-drawing depictions of two other nineteenth-century chiefs, Nyagua 


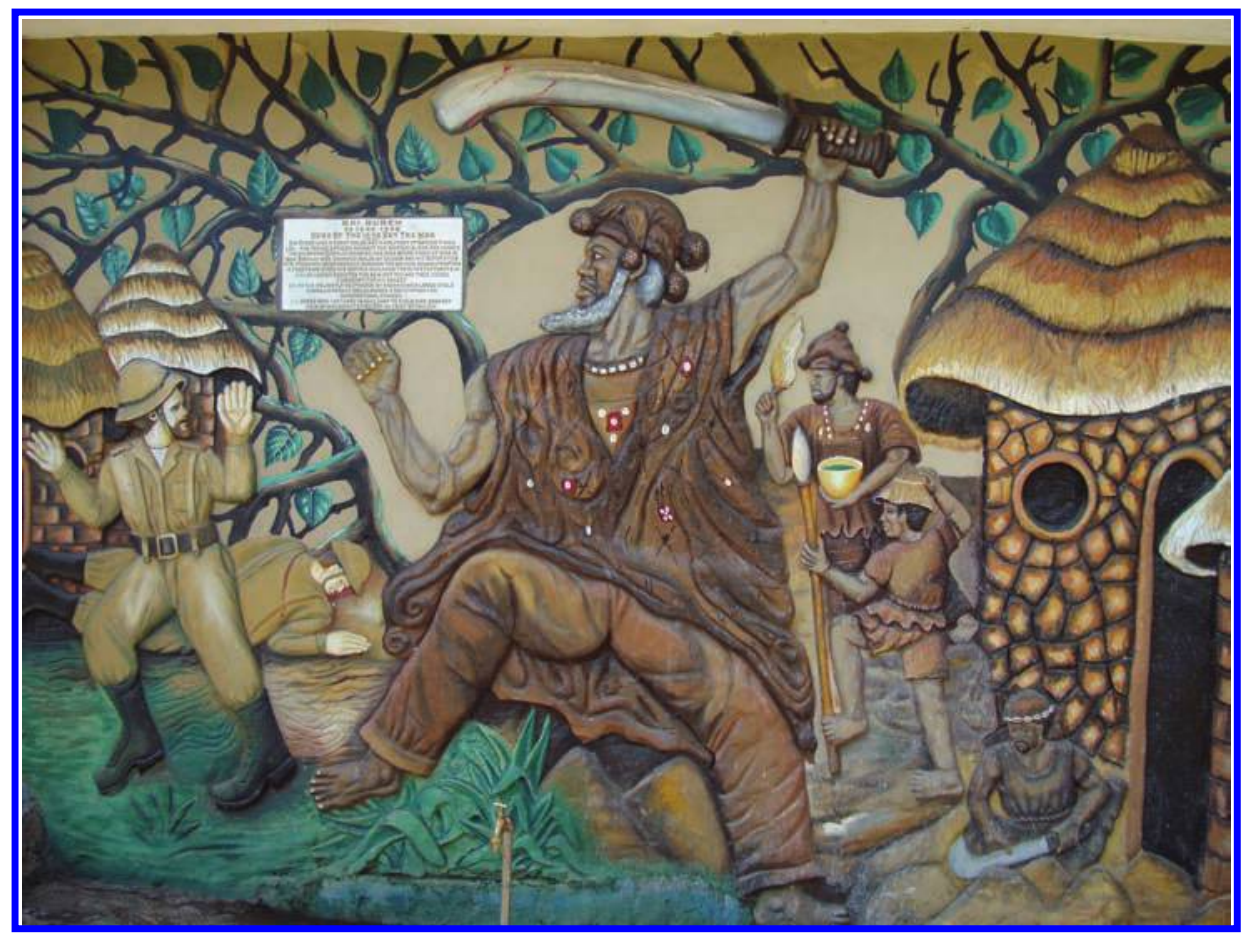

15 Bai Bureh tableau.

16 Drawing by Lt. H. E. Green of Bai Bureh in jail, 1898. Published in the Illustrated London News.

17 The plaster statue of Bai Bureh commissioned by Peace Corps volunteer Gary Schulze and made by Krio carver J.D. Marsh in 1963.

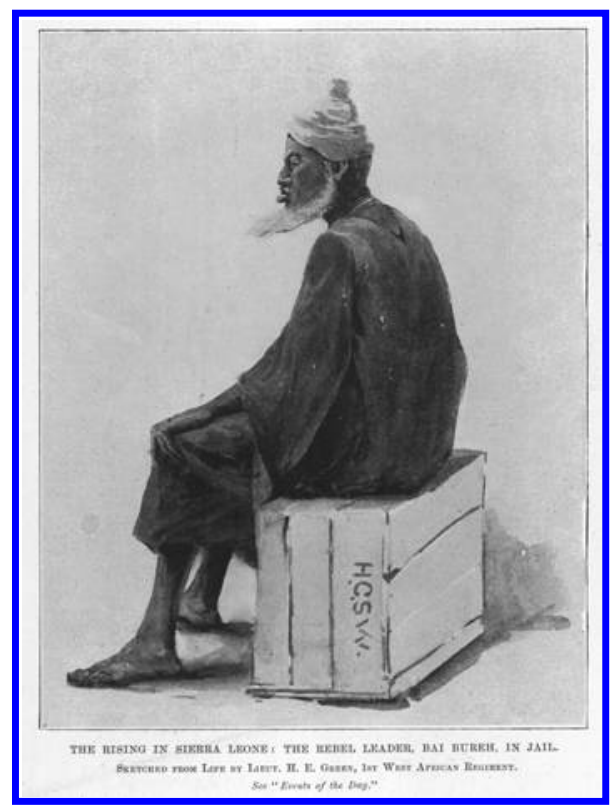

and Kpana Lewis, which are printed in the Heroes book, but these are also composite images, with the hornblower element inspired by a staged visual mise-en-scène conventionalized by colonial photographers. An example may be found in T.J. Alldridge's photograph of Momoh Jah and Momoh Kaikai and their entourages (Fig. 12), published in his 1910 book, A Transformed Colony (Alldridge 1910).

Through the incorporation and combination of selected historical motifs, and the exclusion of others, Madam Yoko is thus placed in a more "authentically Sierra Leonean" context than, say, an urban photographer's studio. This attempt to "indigenize" an essentially colonial archive of images is also evident in the tableaux featuring Sengbe Pieh and Bai Bureh.

The main source for the monument's bas-relief sculpture of Sengbe Pieh (Fig. 13), reproduced uncredited in the Heroes book, is Nathaniel Jocelyn's oil painting of ca. 1840 entitled Cinqué. (Sengbe Pieh was known as Joseph Cinqué in North America.) Whilst Sengbe Pieh has long been a celebrated symbol of the anti-slavery movement in the United States through his association with the 1839 Amistad slave revolt, which has been the subject of numerous academic and popular books and a major Hollywood feature film (Osagie 2000), it was only in the $1990 \mathrm{os}$ that his fame returned to the land of his birth. As Opala notes, in the euphoria that accompanied the 1992 coup, many youth groups in Freetown found in this hero of emancipation "a readymade symbol of their liberation" (Opala 1994:202; see also Christensen 2005). The strength of national feeling for Sengbe Pieh was reflected not only in public art and performance, but also in the fact that it was his portrait, and not that of the Head of State, that featured on the front of the Le50oo note issued by the Bank of Sierra Leone in 1993 (Osagie 1997).

Virtually all the representations of Sengbe Pieh in Sierra Leone, including that which appears on the Le50oo note, are derived from Jocelyn's portrait (Fig. 14). Yet, as Richard Powell has argued,

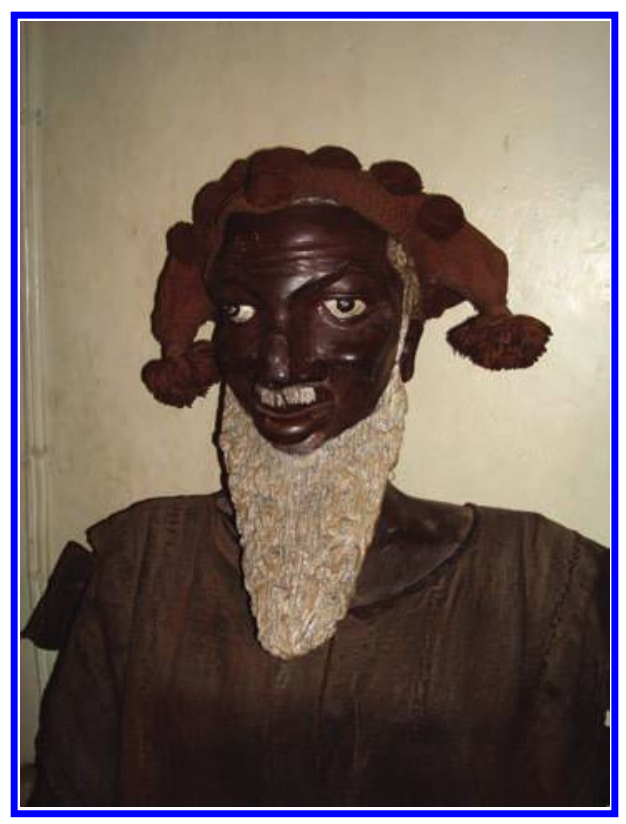

this portrait, in which Sengbe Pieh appears clothed in a white toga-like garment and placed in front of a luminous, quasi-arcadian landscape, is far from naturalistic, but was, rather, a carefully constructed artifact of American abolitionist propaganda:

Against [its] fabricated setting of serrated clouds and colorful bands of mountainous terrain, Cinqué appears more like a Greco-Roman divinity than a brutish African marauder. With clothes that recall 


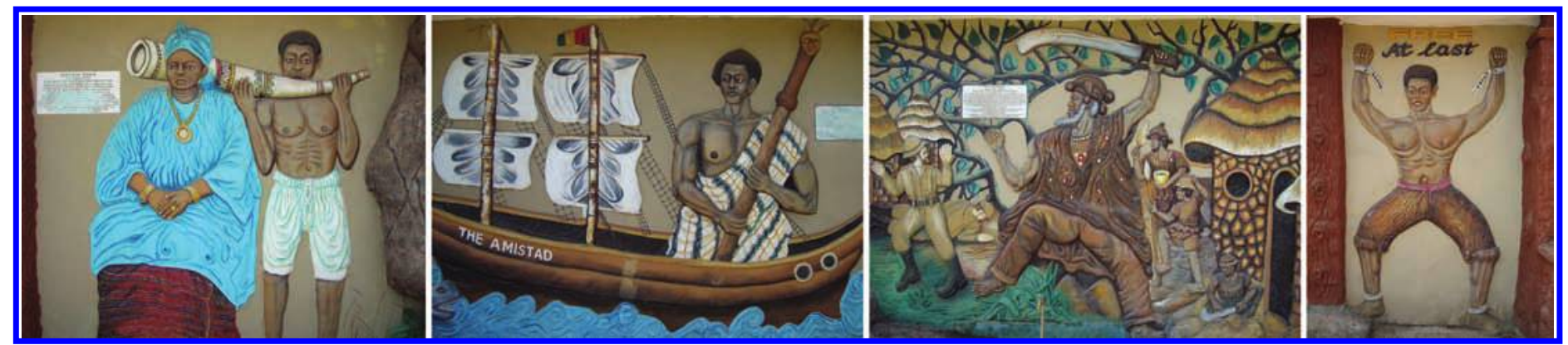

antiquity and a cane staff that evokes the insignia of an ancient shepherd or wanderer, Cinqués image contradicted the prevailing perception of the captive Africans as savages. Instead, Cinqués portrait presented him as the embodiment of a republican (read abolitionist) ideal, an allegorical representation of Christian proselytizing and missionary work in Africa, and a symbol of black resistance and activism in the face of increasing white-on-black violence and sociopolitical unrest. All these manifestations of Cinqué-abolitionist symbol, religious icon, and subversive figure-were contained in the idea of a radical antislavery philosophy, which figured prominently in the events and sentiments surrounding the creation of this portrait (Powell 1997:54).

Jocelyn's portrait was reprinted in the abolitionist press and exhibited at public meetings as an "anti-slavery vehicle" (ibid., p. 68). With its representation of Sengbe Pieh as a "Roman African" in classical garb and placed against a dreamed-up landscape no more "real" than the decorous backdrops of Johnston's Freetown studio, this "quintessential antislavery portrait" (ibid., p. 69) was also quintessentially a work of pastiche. In the present context, what is again interesting to note is the way in which Sierra Leonean artists have selectively reworked elements of this pastiche and recombined them with other motifs to develop an indigenized, postcolonial national iconography. Thus, in the case of the Peace and Cultural Monument representation, while the general posture has been retained, Sengbe Pieh has been given a more muscular physique than in the original, placing emphasis on physical rather than interior strength. Instead of a white toga, he is dressed in a local garment made from country cloth; instead of a nondescript cane, he carries a heavy staff crowned with a carved head-a symbol of Mende chieftaincy.

More obviously, the figure of Sengbe Pieh has been lifted out of its imagined African Arcadia and placed onboard a representation of the Amistad ship itself. Although a contemporary painting of the Amistad exists, this is not widely known and the vessel portrayed in the tableau is somewhat generic, with its identity affirmed through the name emblazoned on its prow. In place of the flag of Honduras under which the Amistad sailed at the time of the revolt, it is the Pan-Africanist colors of green, red, and gold that are unfurled atop its mainmast. An interesting aspect of the assemblage is the relative size of the ship and the towering figure of Sengbe Pieh placed in its stern. Clearly this draws our attention to the Sierra Leonean hero rather than the "background" context, but one might also note the resonance here with local visual conventions, in which important "big men" are often literally portrayed as giants.

Of the heroic triad of Madam Yoko, Sengbe Pieh, and Bai Bureh represented in this section of the monument, the tableau
18 A monumental "film strip" concluding with the "FREE at last" frame.

featuring Bai Bureh marks the most radical departure from the historical sources on which they are based (Fig. 15). Bai Bureh is famed throughout Sierra Leone as the militant leader of an uprising against British colonial rule. As the tableau's plaque states, he is widely regarded as "the hero of the Hut Tax War" of 1898 (Crowder 1970, Abraham 1974). Ironically, however, the only historical representation of this famous chief-the one reproduced in the Sierra Leone Heroes book-is a drawing by a Lt. H.E. Green of the 1st West African Regiment made after Bai Bureh was captured and imprisoned. ${ }^{1}$ The sketch was subsequently published in the Illustrated London News with the caption: "The Rising in Sierra Leone: The Rebel Leader, Bai Bureh, in Jail" (Fig. 16). The once powerful, now defeated Temne-Loko warlord is shown in profile, in a dejected state, sitting on an upturned wooden crate with his hands on his knees-a demonstration of the colonial authority's ability to tame even the most recalcitrant of native leaders. Dixon explained to me that he did not want to reproduce this image of defeat in the monument, but rather wanted to show Bai Bureh "as a gallant hero who fought for his cause."

In his depiction of an altogether more aggressive, unvanquished warrior-hero, Dixon retained the profile of Bai Bureh from Green's drawing, including its protruding beard, full lips, and other facial features. However, these have been combined with another popular representation of Bai Bureh that can be found in Sierra Leone's National Museum. This is a lifesized plaster-of-Paris statue of the warrior-chief that was commissioned by another American Peace Corps volunteer, Gary Schulze, who served as Acting Curator of the Museum in 196263, and was made by a Krio artist named J.D. Marsh (Fig. 17). Green's 1898 drawing was again used as a reference, although Schulze instructed Marsh to use his imagination to recreate Bai Bureh's face in three dimensions. When the statue was delivered to the Museum, Schulze dressed it in an old Kuranko gown and tasselled hat from the Museum's collection, and wired an old sword to the statue's hand (Gary Schulze, personal communication). Despite the incongruity of this attire and the imaginative reconstruction of its face, this statue soon became the authoritative representation of Bai Bureh, reproduced in history books and, indeed, in 1993, printed on a new Le10oo banknote. In the composite Bai Bureh represented at the Peace and Cultural Monument, Dixon combines the profile of Green's origi- 


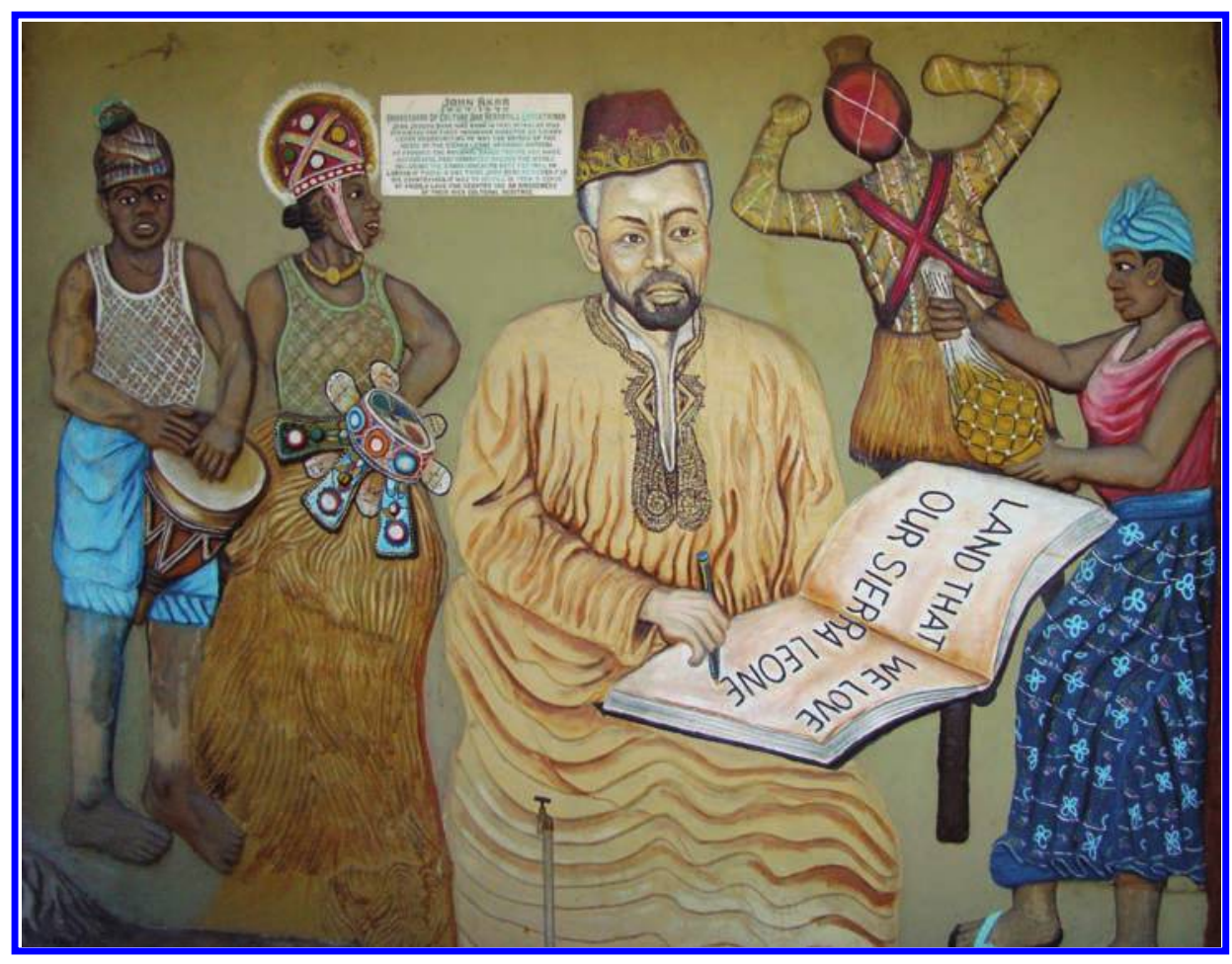

(this page)

19 John Akar tableau.

(opposite, I-r)

20 "Reconciliation" tableau.

21 "Your Attitude Determines Your Altitude" tableau.

nal drawing with the by now familiar tasselled hat and "ronko" gown of the National Museum's statue; but whereas the wired-on sword hangs lifeless in the Museum statue's hand, Dixon raises it aggressively above his warrior's head and smears it with the blood of British soldiers.

Stories abound in Sierra Leone about Bai Bureh's command of spiritual and supernatural powers: his ability to use traditional "medicines" to make himself invisible, render himself impervious to the enemy's bullets, or breathe underwater. These indigenous weapons, which were revived by the kamajor militias during the civil war (Ferme and Hoffman 2004), are evoked in the tableau through the representation of charms sewn into Bai Bureh's garments, by the herbal concoction carried in a bowl by one of "warboys" in the background, and by the animal-tail flywhisk held by the same character. The dramatic scene is set in a native village in the forest, where Bai Bureh and his men are shown defending their homes - the "huts" on which the colonists had the audacity to levy a tax-from the intrusive advances of the white man. While one "Tommy" lies slain, his comrade lifts his arms fearfully in submission and attempts to retreat from an environment in which he evidently does not belong and where his modern weapons are no match for the traditional magic of the indigenous fighters whose strength is rooted in their knowledge of the forest and their alliance with its spiritual powers. Indeed, it is interesting that the Hut Tax War has been racialized in this manner. While their commanding officers were certainly white, the majority of those engaged in fighting the insurgents-and suffering the most casualties-were the black paramilitaries and infantrymen of the Frontier Police Force, the West India Regiment, and a newly formed West African Regiment. Bai Bureh is thus presented here not only a local chief leading his people in resistance to an unfair colonial tax regime, but as an embodiment of autochthonous forces leading the vanguard against the alien presence of European imperialism. Within the mise-en-scène of the pastiche-in which the historical image of the defeated Bai Bureh has been reworked as an image of triumph, and relocated from a Freetown prison to the nation's forested heartland-this heroic battle is portrayed as an unequivocal victory, a key turning point in Sierra Leone's struggle to rid itself from colonial rule.

Forming a linear sequence of frames ranged along the monument's long, southern perimeter, the colorful tableaux that make up the "wall of heroes" can be read almost like a film or comic strip, with each tableau narrating an episode in Sierra Leone's history (Fig. 18). Although the heroes are not placed chronologically in relation to one another, one encounters them as a series of sequential juxtapositions through which the story of Sierra Leone unfolds. This teleological logic is reinforced in a small panel at the extreme right hand side of the wall, immediately adjacent to that depicting Bai Bureh's seemingly decisive victory. It acts as a kind of "full-stop" at the conclusion of this heroic narrative. The panel shows a bare-chested African figure, breaking free of his chains and holding his arms outstretched as a demonstration of his liberation. Above the figure's head are the words "FREE at last." This final frame in the monument's "storyboard" thus gives a particular meaning to the preceding tableaux, fusing Sierra Leone's heritage as the "Province of Freedom," a homeland for the so-called Liberated Africans, with its struggle to free itself from British colonialism. Read in this way, the wall of heroes presents a utopian narrative in which the Sierra Leonean values embodied by these historical personalities-"hope and determination," "outstanding courage," "stubborn independence"-lead to both national and personal emancipation. However, read in relation to the monument as a whole, one is forced to reconcile this utopian vision with the dystopian reality of Sierra Leone's recent history of economic dependency and civil conflict that, 


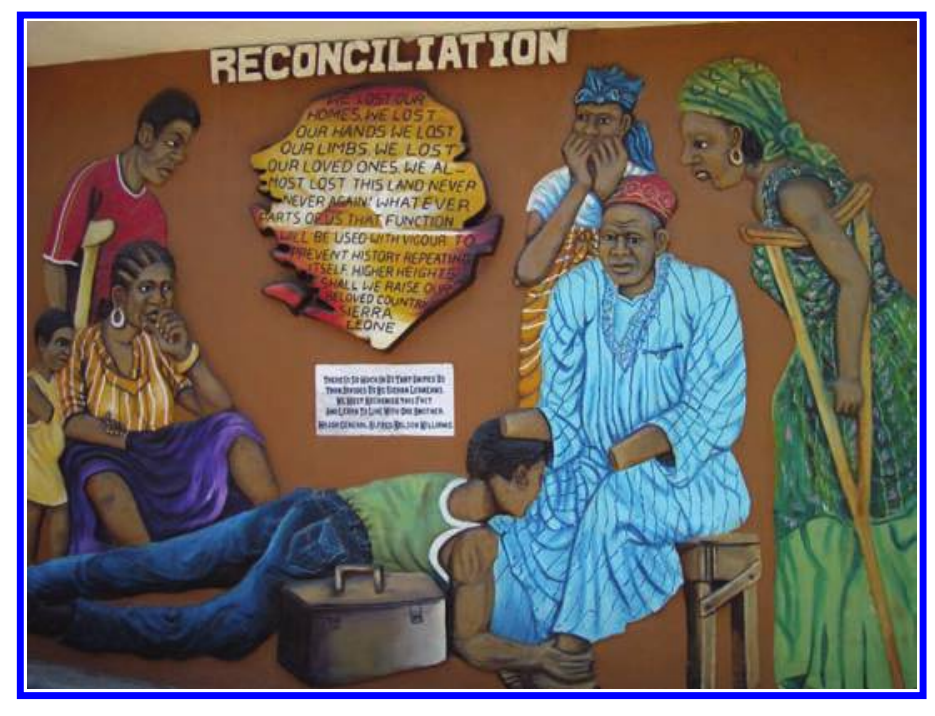

after all, gave rise to the monument in the first place. The monumental pastiche thus embraces its own contradiction and, whether intended or not, makes apparent that it is, at best, an ambiguous freedom that has been won.

\section{A PRAYER FOR THE NATION?}

Before drawing some conclusions, I should like to consider a final series of tableaux that are incorporated into the monument's "wall of heroes," flanking the central sculptures of Siaka Stevens and Sir Milton Margai. I include here the tableau devoted to John Akar, as well as three distinctive panels that convey more explicit messages relating to post-conflict reconciliation and attitudinal change. The colorful Akar tableau provides a bridge between past and future by foregrounding the value of cultural heritage itself as a resource in national self-determination and as a means of inculcating a unifying sense of national pride among Sierra Leoneans (Fig. 19).

The central figure of Akar is again reproduced from the photograph printed in the Sierra Leone Heroes book. The original photograph shows only Akar's head and shoulders, with a framed image of Siaka Stevens and the American flag visible in the background, suggesting that it was taken in 1970 during Akar's brief tenure as the Sierra Leonean Ambassador to the United States. In the bas-relief tableau, the portrait has been extended such that Akar is presented sitting down with a large book open on his lap, on the pages of which he is writing the refrain of Sierra Leone's National Anthem: "Land that we love, our Sierra Leone." (While Akar composed the music of Sierra Leone's National Anthem, the lyric was actually written by Clifford Nelson Fyle.) Surrounding Akar is an assemblage of traditional musicians, dancers, and "masked devils," which represents the National Dance Troupe that Akar founded in 1963. Drawing together accomplished traditional performers from different ethnic groups throughout Sierra Leone, the Troupe toured widely in the mid-196os, won many accolades, and projected a vibrant and positive image of the newly independent nation in the international arena.

This positive image of Sierra Leone has now largely been displaced in the transnational mediascape by images of child soldiers, war atrocities, and poverty, and yet the potential of

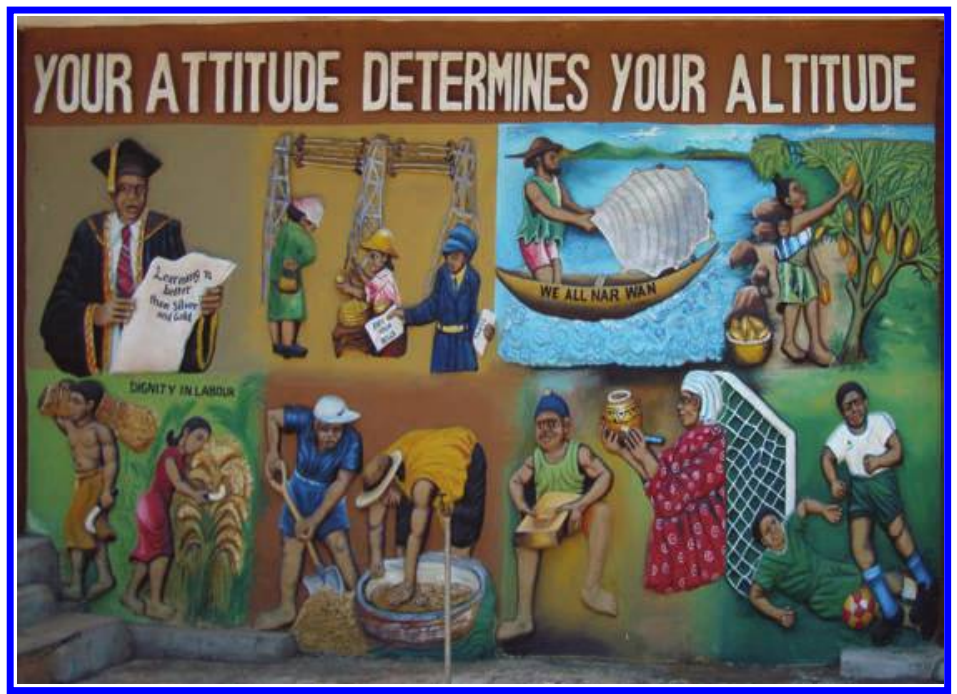

"culture" to shape both internal and external perceptions of the nation, to strengthen national consciousness, and to make a contribution to Sierra Leone's national development goals continues to be recognized and is explicitly articulated in the Government of Sierra Leone's draft cultural policy (Government of Sierra Leone 2011). Whilst the Akar tableau ostensibly celebrates the achievements of another of Sierra Leone's heroes, it might also be regarded more programmatically as a call for a new generation of Sierra Leoneans to follow the example of Akar and, to quote from its accompanying text panel, instil in themselves "a sense of pride, a love for country and an awareness of their rich cultural heritage."

Indeed, this more explicitly programmatic approach is adopted in two tableaux, which respectively bear the titles "Reconciliation" and "Your Attitude Determines Your Altitude." Recalling that the amputation of civilians' limbs was one of the "signature atrocities" of the Sierra Leonean conflict (Berghs 2007), the "Reconciliation" panel shows the contrite figure of an ex-combatant lying prone at the feet of an older man whose hands have been severed (Fig. 20). Beside the ex-combatant is a tool box, which refers to the retraining schemes of Sierra Leone's Disarmament, Demobilization and Reintegration program and signals his willingness to contribute positively to society. The amputee victim lays the stub of one arm on the ex-combatant's head in a gesture of forgiveness, while other victims of amputation look on with varying expressions: some gaze in disbelief, while others seem inspired by the example set by the older man, perhaps also ready to forgive. At the center of the tableau is the cut-out shape of Sierra Leone, onto which is painted a sunrise, suggesting a "new dawn," and the following text, the first part of which seems to speak for the assembled victims:

We lost our homes. We lost our hands. We lost our limbs. We lost our loved ones. We almost lost this land. Never, never again! Whatever parts of us that function will be used with vigour to prevent history repeating itself. Higher heights shall we raise our beloved country, Sierra Leone.

Beneath this is the previously quoted personal message of Major General Nelson-Williams entreating his compatriots to 
recognize their commonalities and learn to live with one another.

The call for Sierra Leoneans to "embrace change," including changing their attitudes towards each other, and their attitude towards "work and responsibilities," was a prominent theme in Koroma's inaugural presidential speech (Awoko 2007). Alongside promises of a "zero tolerance" policy on corruption, a new Secretariat for Attitudinal and Behavioural Change was established in the Ministry of Information and Communication in 2008 to promote this agenda.

The theme of attitudinal change has also been incorporated into the Peace and Cultural Monument in the "Your Attitude Determines Your Altitude" tableau (Fig. 21). The clearly stated message here is that, with the right attitude, ordinary people can raise themselves out of poverty and achieve "higher heights," both personally and for their nation. This tableau includes eight panels, each conveying key messages. Thus, at top left, reflecting the high value placed on education, a graduate holds his diploma on which is written "Learning Is Better than Silver and Gold." Next to this is a panel framed by newly erected power pylons, a symbol of infrastructural development, with a trader selling her goods to a customer; in the foreground a uniformed individual holds two notices, one stating "Pay Your Bills," the other "Taxes." The remaining six panels relate to the slogan "Dignity in Labour" and show various occupations: fishing, picking fruit, harvesting rice, mixing concrete, engaging in traditional music and crafts and, most aspirationally, playing football for the national team. The fisherman's boat near the center of the tableau carries the name "We all nar wan"- "we are all one"-promoting unity not only across ethnic boundaries, but also, presumably, across occupational, class, gender, and other social divisions as represented in the various characters portrayed. This is perhaps the most explicitly pedagogical element of the monument's assemblage: a lesson in how to be a responsible, law-abiding, tax-paying, hard-working, modern citizen.

At Sierra Leone's new Peace and Cultural Monument it is clear that the arts of postcolonial pastiche have been employed to articulate a vision of national aspiration, in which images of poverty, suffering, and conflict have been excised or else placed in a past that has been overcome. Caught between this utopian vision and the dystopian realities facing many Sierra Leoneans today, this is a monument of hope, a visual and material manifestation of Sierra Leone's post-conflict political rhetoric of reconciliation, attitudinal change, and social and economic transformation. It is the nation's prayer for itself. Indeed, in a final tableau on the monument's wall of heroes, superimposed on a huge outline map of Sierra Leone, beneath hands joined in supplication, a prayer is precisely what we find. Given the multiculturalist "unity in diversity" message of the monument and the fact that an estimated $70 \%$ of Sierra Leone's population are Muslim, it is an odd oversight (or a religious conviction) of the monument-makers that it is only a Christian god that is addressed in this entreaty. Nevertheless, here is voiced: gratitude to "the heroes who fought for freedom and reconciliation;" desire that all Sierra Leoneans might share values of "integrity, patriotism, reconciliation, and selfless sacrificial service to the nation;" and confidence that "a bright future" is indeed ordained for the country-"a future of peace, progress, and prosperity."

\section{CONCLUSIONS:}

\section{NATIONAL PEDAGOGY AND MONUMENTAL AMBIVALENCE}

It remains to be seen what Sierra Leoneans will make of this new landmark in Freetown's cityscape. Will it be perceived as a prayer for the nation or a lecture from the Government on "good citizenship"? Will the populace perceive it as a cynical attempt to restore trust in a military that once preyed upon those it should have been protecting? Or might it yet act as a site of symbolic reparation and national healing as advocated by the commissioners of the TRC? Perhaps the monument will continue to be met with indifference-at least until the entrance fees are removed. Or perhaps the very assumption that its purpose is to be visited is a false one: that it is, rather, its existence that matters most (Rowlands 2011:S36). I suspect that this indeterminacy of meaning will not be resolved and is an inherent quality of the monument as a work of pastiche. As Hoesterey argues, it is the beholder who is challenged "to detect and decipher the intertextual fabric" of such a work (2001:31).

Rather than a shallow form of bricolage or imitation, I have argued that pastiche is a complex narrative mode. Based on the principles of accumulation and reconfiguration, pastiche gathers images, forms, and statements from a cultural and historical reservoir, articulating relationships between present and past and establishing juxtapositions that draw attention to its multiple temporalities. On the one hand we detect in the Sierra Leone Peace and Cultural Monument a "teleology of progress," a "nationalist pedagogy" which conjunctively relates the monument's disparate temporalities to create a "spatial expression of a unitary people" (Bhabha 1990:294): "we all nar wan" in a shared cultural heritage and a shared hope for the future. On the other hand, however, the form of the monument is itself profoundly disjunctive. The monument thus disrupts its own pedagogical purpose, exposing the constructedness of its narrative contrivances, displaying their inconsistencies and omissions.

As an exemplar of postcolonial pastiche, the monument thus contributes to our understanding of the making of postcolonial memory and political subjectivities in contemporary West Africa (Werbner 1998, De Jong and Rowlands 2007). It speaks to the need to revise the past to serve the needs of the present: for example, requiring certain acts of treachery to be forgotten, or "repatriating" images and histories that have been "exiled" in the colonial archive. It alerts us to the power of narrative form over the "chaos of phenomena" (Lorenz 1998): for example, integrating the ambiguities of civil conflict into what is shaped as a long, triumphant history of national self-determination and national self-deliverance from slavery and colonial oppression. It shows us how present political ideologies of modernization and development are made continuous with such progressive historical narratives: that, while certain pasts must not be allowed to repeat themselves, others are to be emulated and reproduced to bring about a brighter future. As William Gass argued years ago, "most monuments lie" (Gass 1982:140), but few lie so openly or, perhaps, with such good intent.

PAUL BASU is Reader in Material Culture and Museum Studies at University College London and a managing editor of the Journal of Material Culture. He recently led a three-year research project resulting in the creation of the www.sierraleoneheritage.org digital heritage resource. paul. basu@ucl.ac.uk 


\section{Acknowledgements}

Research for this article was funded by the UK's Arts and Humanities Research Council as part of a wider-ranging three-year project entitled "Reanimating Cultural Heritage: Digital Repatriation, Knowledge Networks and Civil Society Strengthening in Post-Conflict Sierra Leone." I am extremely grateful for this support. For permission to reproduce images, I thank Gary Schulze and the Royal Pavilion and Museums, Brighton and Hove. I should also like to thank Michael Rowlands and two anonymous referees for their valuable comments on earlier drafts of this article.

1 While this article was going to press a hitherto unknown photograph of Bai Bureh came to light and was acquired by Gary Schulze. The photograph was taken by Lieutenant Arthur Greer of the West India Regiment while Bai Bureh was being held prisoner in Freetown in 1898

\section{References cited}

Abraham, Arthur. 1974. "Bai Bureh, the British, and the Hut Tax War." International Journal of African Historical Studies 7(1):99-106.

Alldridge, Thomas J. 1910. A Transformed Colony: Sierra Leone, as It Was, and as It Is. London: Seeley.

Awoko. 2007. "At His Inauguration Ernest Calls for 'Change"' November 16, 2007. http://www.awoko. org/2007/11/16/at-his-inauguration-ernest-calls-for"change", accessed July 26, 2011.

Basu, Paul. 2007. "Palimpsest Memoryscapes: Materializing and Mediating War and Peace in Sierra Leone." In Reclaiming Heritage: Alternative Imaginaries of Memory in West Africa, ed. Ferdinand de Jong and Michael Rowlands, pp. 231-59. Walnut Creek: Left Coast Press.

2008. "Confronting the Past? Negotiating a

Heritage of Conflict in Sierra Leone." Journal of Material Culture 13(2):153-67.

Berghs, Maria. 2007. "Disability as Embodied Memory? Questions of Identity for the Amputees of Sierra Leone." Wagadu 4:78-92.

Bhabha, Homi K. 1990. "DissemiNation: Time, Narrative, and the Margins of the Modern Nation." In Nation and Narration, pp. 291-322. London: Routledge.

Binyon, Laurence. 1914. "For the Fallen." The Times, September 21, p. 9 .

Christensen, Matthew J. 2005. "Slave Rebellions Past, Rebel War Present: Historical Representation during Sierra Leone's Civil War." In Representations of Violence: Art about the Sierra Leone Civil War, ed. Patrick K. Muana and Chris Corcoran, pp. 21-28. Madison, WI: 21st Century African Youth Movement.
Churchill, Winston. 1940. "The Few." Address to the House of Commons, London, August 20. Hansard HC Deb 20 August 1940, vol. 364, cols. 1132-274.

Crowder, Michael (with LaRay Denzer). 1970. "Bai Bureh and the Sierra Leone Hut Tax War of 1898." In Protest and Power in Black Africa, ed. Robert Rotberg and Ali Mazrui, pp. 169-212. Oxford: Oxford University Press.

De Jong, Ferdinand, and Rowlands, Michael, eds. 2007. Reclaiming Heritage: Alternative Imaginaries of Memory in West Africa. Walnut Creek: Left Coast Press.

Dyer, Richard. 2007. Pastiche. Abingdon: Routledge.

Ferme, Mariane C., and Danny Hoffman. 2004. "Hunter Militias and the International Human Rights Discourse in Sierra Leone and Beyond." Africa Today 50 (4):73-95.

Fyle, C. Magbaily. 2006. Historical Dictionary of Sierra Leone, new ed. Lanham, NJ: Scarecrow Press.

Gass, William H. 1982. "Monumentality/Mentality." Oppositions 25:127-44.

Hoesterey, Ingeborg. 2001. Pastiche: Cultural Memory in Art, Film, Literature. Bloomington: Indiana University Press.

Hoffer, Carol P. 1974. "Madam Yoko, Ruler of the Kpa Mende Confederacy." In Women, Culture, and Society, ed. Michele Z. Rosaldo and Louise Lamphere, pp. 173-87. Stanford, CA: Stanford University Press.

Government of Sierra Leone. 2011. Unpublished cultura policy document. Freetown: Ministry of Tourism and Cultural Affairs.

Kabba, M.R.A., ed. 1988. Sierra Leonean Heroes: Fifty Great Men and Women Who Helped to Build Our Nation, 2nd ed. Freetown: Government of Sierra Leone.

Koroma, Ernest. 2010. "Statement by His Excellency the President and Commander in Chief Dr Ernest Bai Koroma on the unveiling and commissioning of the Republic of Sierra Leone Armed Forces War Monument on 18 February 2010." http://www.statehouse.gov.sl/ index.php? option $=$ com_content\&view $=$ article\&id $=163$, accessed July 26, 2011.

Lorenz, Chris. 1998. "Can Histories Be True?: Narrativism, Positivism, and the 'Metaphorical Turn." History and Theory 37:309-29.

Mansaray, John. 2006. "Bomaru Residents not Happy with Government of Sierra Leone." Awareness Times, September 14, 2006, http://news.sl/drwebsite/exec/view. cgi? archive $=3 \&$ num $=3587$, accessed July 26, 2011.

Opala, Joseph A. 1994. “'Ecstatic Renovation!': Street Art Celebrating Sierra Leone's 1992 Revolution.” African Affairs 93:195-218.
Osagie, Iyunolu F. 1997. "Historical Memory and a New National Consciousness: The Amistad Revolt Revisited in Sierra Leone." The Massachusetts Review, 38 (1): 63-83. 2000. The Amistad Revolt: Memory, Slavery, and the Politics of Identity in the United States and Sierra Leone. Athens: University of Georgia Press.

Powell, Richard J. 1997. "Cinqué: Antislavery Portraiture and Patronage in Jacksonian America." American Art 11 (3):48-73.

Robertson, Roland. 1995. "Globalization: Time-Space and Homogeneity-Heterogeneity." In Global Modernities, ed. Michael Featherstone, Scott Lash, and Roland Robertson, pp. 25-44. London: Sage.

Rowlands, Michael. 1998. “Trauma, Memory, and Memorials." British Journal of Psychotherapy 15 (1):54-64.

2009. "Africa on Display: Curating Postcolonial Pasts in the Cameroon Grassfields." In Postcolonial Archaeologies in Africa, ed. Peter R. Schmidt, pp. 149-62. Sante Fe: School for Advanced Research Press. 2011. "Of Substances, Palaces, and Museums The Visible and the Invisible in the Constitution of Cameroon." Iournal of the Royal Anthropological Institute (n.s.) 17:S23-S38.

Rubin, Arnold. 1975. "Accumulation: Power and Display in African Sculpture.” Artforum 13 (9):35-47.

Sajuma, Foday. 2008. "Memorials in Sierra Leone: An Honour to the Dead or a Painful Reminder of War?" http://www.communicatingjustice.org/en/stories/18072008_memorials_sierra_leone_honour_dead_ or_painful_reminder_war, accessed July 26, 2011.

Taussig, Michael. 1993. Mimesis and Alterity: A Particular History of the Senses. New York: Routledge.

Truth and Reconciliation Commission. 2004. Witness to Truth: Report of the Sierra Leone Truth and Reconciliation Commission, vol. 2. Freetown: Truth and Reconciliation Commission.

United Nations. 2009. "Human Development Report" http://hdrstats.undp.org/en/indicators/103.html, accessed July 26, 2011.

Viditz-Ward, Vera. 1987. "Photography in Sierra Leone, 1850-1918." Africa 57 (4):510-18.

Werbner, Richard P., ed. 1998. Memory and the Postcolony: African Anthropology and the Critique of Power. London: Zed Books.

Zack-Williams, A.B. 1997. "Kamajors, 'Sobel' and the Militariat: Civil Society and the Return of the Military in Sierra Leonean Politics." Review of African Political Economy 24 (73):373-80. 
This article has been cited by:

1. Gitti Salami. 2016. The Materiality of Cement in the Cultural Matrix of the Middle Cross River Region. African Arts 49:3, 32-47. [Citation] [Full Text] [PDF] [PDF Plus] 